\title{
Phylogeography of high Andean killifishes Orestias (Teleostei: Cyprinodontidae) in Caquena and Lauca sub-basins of the Altiplano (Chile): mitochondrial and nuclear analysis of an endangered fish
} \author{
Violeta Cárcamo-Tejer ${ }^{1}$, Irma Vila ${ }^{1}$, Francisco Llanquín-Rosas ${ }^{1}$, Alberto Sáez-Arteaga ${ }^{2}$, Claudia Guerrero-Jiménez
Corresp. 2 \\ ${ }^{1}$ Departamento de Ciencias Ecológicas, Universidad de Chile, Santiago, Región Metropolitana, Chile \\ 2 Instituto de Ciencias Biomédicas, Facultad de Ciencias de la Salud, Universidad Autónoma de Chile, Temuco, Región de la Araucanía, Chile \\ Corresponding Author: Claudia Guerrero-Jiménez \\ Email address: claudia.guerrero@uautonoma.cl
}

From the early Miocene, the uplift of the Andes Mountains, intense volcanic activity and the occurrence of successive periods of dryness and humidity would have differentially influenced the modification of Altiplano watersheds, and consequently the evolutionary history of the taxa that live there.

We analyzed Orestias populations from the Caquena and Lauca Altiplanic sub-basins of northern Chile to determine their genetic differentiation and relationship to their geographical distribution using mitochondrial (D-loop) and nuclear (microsatellite) molecular markers and to reconstruct its biogeographic history on these sub-basins.

The results allowed reconstructing and reevaluating the evolutionary history of the genus in the area; genic diversity and differentiation together with different founding genetic groups suggest that Orestias have been spread homogeneously in the study area and would have experienced local disturbances that promoted isolation and diversification in restricted zones of their distribution. 


\section{Phylogeography of high Andean killifishes Orestias}

\section{2 (Teleostei: Cyprinodontidae) in Caquena and Lauca}

3 sub-basins of the Altiplano (Chile): mitochondrial and

4 nuclear analysis of an endangered fish.

Violeta Cárcamo-Tejer ${ }^{1}$, Irma Vila ${ }^{1}$, Francisco Llanquín-Rosas ${ }^{1}$, Alberto Sáez-Arteaga ${ }^{2}$, Claudia

7 Guerrero-Jiménez $2^{2 *}$

8

${ }^{1}$ Departamento de Ciencias Ecológicas, Universidad de Chile, Santiago, Región Metropolitana, Chile

${ }^{2}$ Instituto de Ciencias Biomédicas, Facultad de Ciencias de la Salud, Universidad Autónoma de Chile, Temuco, Región de la Araucanía, Chile

*Corresponding Author:

Claudia Guerrero-Jiménez

Email address: claudia.guerrero@uautonoma.cl

\section{Abstract}

From the early Miocene, the uplift of the Andes Mountains, intense volcanic activity and the occurrence of successive periods of dryness and humidity would have differentially influenced the modification of Altiplano watersheds, and consequently the evolutionary history of the taxa that live there.

We analyzed Orestias populations from the Caquena and Lauca Altiplanic sub-basins of northern Chile to determine their genetic differentiation and relationship to their geographical distribution using mitochondrial (D-loop) and nuclear (microsatellite) molecular markers and to reconstruct its biogeographic history on these sub-basins.

The results allowed reconstructing and reevaluating the evolutionary history of the genus in the area; genic diversity and differentiation together with different founding genetic groups suggest that Orestias have been spread homogeneously in the study area and would have experienced local disturbances that promoted isolation and diversification in restricted zones of their distribution.

\section{Introduction}

Mitochondrial and nuclear markers analyzed in a geographic context have been used to elucidate 
mechanisms, as well as to infer the evolutionary history of populations, deepening the knowledge generated by phylogeography since it was pointed out by Avise in 1987 (Avise, 1998; Hickerson et al., 2010). In addition, this type of analysis can be used to know and explain the structure and genetic diversity of populations in a more efficient way (Yi et al., 2020). The information that they can generate is useful when making conservation decisions around those populations where the delimitation of species has not been well defined considering that the diversification of species can be explained by population-level evolutionary processes and making inferences from geographic distributions of genealogical lineages (Katongo et al., 2005; Rissler, 2016). Also considering small and isolated populations that face a high degree of threat such as loss and fragmentation of habitat, contamination or introduction of invasive species and whose small population sizes make them more likely to generate inbreeding, loss of genetic diversity and therefore the decrease in their ability to adapt to future changes (Frankham, 2005; Rubinoff et al., 2020), as those freshwater fishes that inhabit environments prone to desiccation. Phylogeographic studies in freshwater fishes have shown that they have a marked phylogeographic structure that is strongly linked to historical changes in the ecology and geology of the systems they inhabit and can be a good study model to analyze speciation processes associated with divergence adaptive and reproductive isolation (Beheregaray, 2008). In addition, it is known that some groups of organisms have an unusually high rate of speciation, reason why they are ideal for studying genetic differentiation processes in shorter times (Kornfield \& Smith, 2000; Salzburger et al., 2005; Mehner et al., 2010; Bezault et al., 2011; Marques et al., 2019). "Killifishes" are Cyprinodontiforms (Berg, 1940), freshwater fishes that have been widely studied due to their morphological specialization, life history traits and geographic distribution that includes America, the Mediterranean, Southeast Asia and Africa (Parker \& Kornfield, 1995; Capobianco \& Friedman, 2018). The monophyly of the Cyprinodontiform group and its subdivision into suborders Aplocheiloidei and Cyprinodontoidei has been supported by morphological and genetic studies (Parenti, 1981; Setiamarga et al., 2008; Pohl et al., 2015), however, genealogical relationships within each of these groups remain controversial since their fossil record is still scarce; it has been postulated that their present continental radiation has been mediated by a large-scale vicariance or dispersion radiation (Capobianco \& Friedman, 2018). The current presence of this group on both sides of the Atlantic Ocean can be explained by their particular physiology, life history and behavior, which have allowed them to explore habitats with ephemeral waters and adapt to them (Parenti, 1981; Capobianco \& Friedman, 2018; Vrtílek et al., 2018). In the family Cyprindontidae (Cyprinodontoidei) the genera Orestias (Parenti, 1984a) and Pseudorestias (Arratia et al., 2017) inhabit exclusively aquatic systems in the Andes Highlands, including the extensive inter-Andean plain or Altiplano between $15-27^{\circ} \mathrm{S}$ whose average altitude exceeds 3000 meters (Isacks, 1988; Muñoz \& Charrier, 1996). The aquatic systems of the Altiplano and their associated biota are exposed to extreme environmental conditions including altitude, wide ranges of salinity, radiation, wind and high daily temperature variation. In these systems there are places where surface waters freeze at night and thaw during the day. There is a negative hydrological regime with well-defined wet (January-March) and dry seasons (April to December) that constantly modulate the superficial water courses (Kött, Gaupp \& Wörner, 1995; Rundel \& Palma, 2000; Lambrinos, Kleier \& Rundell, 2006; Márquez-García et al., 2009; Demergasso et al., 2010; Scott, 2010; Vila et al., 2013; Scott et al., 2015). 
79 Geomorphologic and climatic changes occurred during the Miocene and more strongly in the

80 Plio-Pleistocene ( 5-2 million years ago or MyBP) with the rise of the Andes Range and the

81 major elevation of the Altiplano, produced significant disturbances in South American

82 hydrography; only those taxa which adapted to these variations survived. It is believed that the

83 Orestias cyprinodontoid ancestor colonized northern South America 80-100 MyBP (late

84 Jurassic-Cretaceous) and reached the territory we know today as the Altiplano before its uplift.

85 Survival and dispersion after the uplift would have been favored given its tolerance to

86 environmental conditions such as altitude and salinity. The existence of large water bodies that

87 were progressively subdivided into several paleo-lakes facilitated the disaggregation and

88 reproductive isolation of the ancestral population (Villwock, 1983) resulting in new genetic

89 diversity. Lake Titicaca, today one of the largest lakes in South America, has been postulated as

90 the center of radiation of the genus, mainly due to its effluent Desaguadero River that flows

91 south to Lake Poopó (Villwock, 1983; Lüssen, Falk \& Villwock, 2003; Scott, 2010; Vila et al.,

92 2013).

93 Although different approaches have been used to obtain information about genetic, ecological

94 and evolutionary characteristics of Orestias populations (Lüssen, Falk \& Villwock, 2003; Vila,

95 Pardo \& Scott, 2007; Maldonado et al., 2009; Peña, 2010; Esquer Garrigos et al., 2011; Morales,

96 Vila \& Poulin, 2011; Vila et al., 2013; Cruz-Jofré et al., 2014, 2016; Esquer-Garrigos et al.,

97 2015; Guerrero-Jiménez et al., 2015; Arratia et al., 2017; Morales Henriquez, 2018), aspects like

98 its evolutionary history and biogeography are still poorly understood.

99 Orestias has been described as a species flock (Parenti, 1984b; Northcote, 2000; Esquer-

100 Garrigos, 2013) and so far, 47 species have been described in the highland systems of Peru,

101 Bolivia and Chile (Eschmeyer \& Fong, 2019); seven of them inhabit the Chilean Altiplano

102 between $17-27^{\circ} \mathrm{S}$ (Arratia et al., 2017) whose conservation status on the Red List of Threatened

103 Species of the International Union for Conservation of Nature and Natural Resources (IUCN)

104 includes "data deficient", "vulnerable" and "near threatened" (Esmaeili, Asrar \& Gholamifard,

105 2018). Other authors have indicated them as "endangered" given the fragility of the ecosystems

106 that inhabit and the threats to which they are exposed (Vila, Pardo \& Scott, 2007; Vila et al.,

107 2007). In Chile, the Altiplano basins are subdivided into sub-basins depending on the tributaries

108 that carry out the drainage towards the main river course (DGA, 2014). In this study we

109 examined the Caquena and Lauca sub-basins, which are the nearest area to Lake Titicaca in the

110 Chilean Altiplano, which is why their Orestias populations have special relevance. Studies on

111 the gastropod Biomphalaria which co-inhabits with Orestias indicated differentiation between

112 populations of the Lauca and Caquena sub-basins, each belonging to a different lineage with a

113 divergence time of 0.68-0.34 million years. Recent isolation processes of aquatic systems would

114 have occurred within Caquena compared to those within the Lauca sub-basin (Collado, Vila \&

115 Méndez, 2011; Collado, Salinas \& Méndez, 2014). A phylogeny of Orestias populations of

116 Chilean species (Vila et al., 2013) constructed from mitochondrial DNA showed four

117 differentiated clades which are spatially segregated, suggesting a pattern consistent with a

118 differentiation process by vicariance and found that individuals belonging to the locality of 
119 Umaqui (Caquena sub-basin) appear in a separate clade along with those of southern sub-basins

120 of the Chilean Altiplano, however, there is no evidence about the processes of genetic

121 differentiation of the genus in this sub-basin. All species described in Lauca sub-basin are

122 grouped in one clade. However, the study of Peña (2010) in Lauca National Park (LNP)

123 highlighted the genetic coherence (mitochondrial markers) between specimens from the northern

124 and middle regions of the sub-basin, suggesting divergence from the southeastern region. In

125 addition, Guerrero-Jiménez et al. (2017), using mitochondrial (D-loop) and nuclear DNA (8

126 microsatellites) found that the genetic patterns of differentiation would correspond to an incipient

127 speciation in allopatry due to the signs of population expansion and the mixed genetic patterns.

128 Their results were associated with the processes of fragmentation of the systems in the sub-basin

129 during the Pleistocene-Holocene, whose main detonator would have been the collapse of

130 Parinacota volcano's old cone 12,500 years before present (hereinafter yBP), dating that has

131 been adjusted to $8,800 \mathrm{yBP}$ (Jicha et al., 2015), which would have caused a significant

132 transformation in the landscape, changed the direction of the main river course and produced

133 three systems that remain until today: Lake Chungará, Cotacotani Lagoons and the Lauca River

134 (Sáez et al., 2007; Giralt et al., 2008).

135 The Caquena and Lauca sub-basins are separated by a volcanic cord of Pleistocene origin whose

136 summits rise above 4000 meters; both being part of larger basins shared with the countries of

137 Bolivia and Peru and both lithological covers have been described as Tertiary superior to

138 Quaternary origin (Niemeyer, 1982), but they have different characteristics despite their

139 geographical proximity. The area of Caquena sub-basin is $1,268 \mathrm{Km} 2$; it is limited by the slopes

140 of adjacent terraces, has an average elevation of 4230 m.a.s.l. and is widely covered by wetlands

141 (bofedales); the Caquena River course goes from south to north. Lauca sub-basin has a surface of

142 2406 Km2 with an average elevation of 4,295 m, has varied types of aquatic systems including

143 lakes, lagoons, and wetlands (bofedales); the Lauca River runs from north to south (Salazar,

144 1997). This area is interesting to analyze evolutionary relations of Orestias, especially

145 considering its geographical proximity to the proposed center of radiation of the genus and also,

146 that given its rapid speciation characteristics and to the history of the geological, hydrological

147 and climatic changes that have occurred in the Altiplano since its formation (Morales et al.,

148 2011). Differentiation processes linked to adaptation during short evolutionary periods has been

149 evidenced in fishes of the Cichlidae family that inhabit Victoria Lake in Africa, or Apoyeque

150 Lake in Nicaragua where a sympatry process could explain the high diversity of species within

151 the same lake (Elmer et al., 2010; Takuno et al., 2019). Furthermore, some species of cichlids

152 have shown similar morphological features (Kocher, 2004) where has been postulated a radiation

153 of species related to colonization events by different lineages due to allopatry. This vicariant

154 process would be related to substantial changes in the climate and rainfall regimes that would

155 have fragmented the water systems on drought periods. According to this, we consider that the

156 genus Orestias represents an excellent model to probe phylogeographic hypothesis on a

157 historically and successively fragmented populations. 
158 Given the high specialization of Orestias to the different aquatic systems of the Altiplano and

159

160

161

162

163

164

165

166

167

168

169

170

171

172

173

174

175

176

177

178

179

180

181

182

183

184

185

186

187

188

189

190

191

that Caquena and Lauca sub-basins conform differentiated hydrological units, we hypothesized that genetic variation in Orestias populations would be reflected in these two units and could be a response to geological events that affected their evolutionary history. Thus, the objective of this study was to analyze the phylogeographic relationships of Orestias populations in the Caquena and Lauca sub-basins using mitochondrial and nuclear molecular markers (mitochondrial D-loop and microsatellites) to provide evidence of its evolutionary history.

\section{Materials \& Methods}

\section{Sampling sites}

Fish samples were captured from Caquena and Lauca sub-basin, during the years 2016-2017. The Caquena sub-basin area considers three locations: Caquena, Colpa and Umaqui. The southern zone of the Lauca sub-basin considers two locations: Ancuta and Paquisa (GenBank accession numbers BankIt2361457: MW149163-MW149238). To complement the information of the geographical distribution of the genus, data from Guerrero-Jiménez et al. (2017) were included (GenBank accession numbers BankIt1931003: KX498091- KX498358) from four representative localities of genetic diversity in northern zone of the Lauca sub-basin: Chuviri, Copapujo, Lauca and Misituni. These locations were selected from the pool of available data after a previous analysis that allowed us to choose those populations that turned out to be more informative for the representation of the genetic diversity of the northern zone of the Lauca subbasin (data not shown). The geographic data of the locations considered in this work are shown on Fig. 1 and Table 1.

\section{Sampling and preservation of samples}

The fish were obtained according to research fishing permit number 1103-2015 of the Chilean Undersecretary of Fisheries (see S1) and were captured with manual fishing nets. The number of samples obtained did not significantly affect the conservation status of the populations. Euthanasia was performed with $100 \mathrm{mgl}-1$ of tricaine methanesulfonate. They were preserved in 95\% ethanol and stored at the Laboratorio de Limnología of Universidad de Chile.

The identification of individuals was carried out through a review of specialized literature and consultation with experts, being classified as Orestias sp. for the Caquena sub-basin locations and as Orestias of laucaensis for Ancuta and Paquisa. Regarding the other locations, they had been classified by Guerrero-Jiménez et al. (2017) as Orestias laucaensis for those individuals from Lauca and Misituni. For those locations of Chuviri and Copapujo, they were identified as Orestias sp.

\section{DNA extraction}


192 DNA was extracted from muscle tissue obtained by dissecting the area on the pectoral fin. The

193

194

195

196

197

198

199

200

201

202

203

204

205

206

207

208

209

210

211

212

213

214

215

216

217

218

219

220

221

222

223

224

225

226

muscle is dried and then pulverized, after which it is subjected to the action of proteinase $\mathrm{K}$ and is treated with repeated cycles of immersion in saline dilutions and centrifugation according to the procedure indicated in Aljanabi \& Martinez, (1997). After extraction, the purity and concentration of the DNA samples was determined by spectrophotometry with the Thermo Scientific NanoDropTM 1000 spectrophotometer.

\section{Amplification/genotyping and data analysis}

\section{Mitochondrial DNA}

The control region of mitochondrial DNA (D-loop) was amplified by PCR using specific primers for the genus: Forward 5' ACC CCT AAC TCC CAA AGC T 3'; Reverse 5' TGA TAG TAA AGT CAG GAC CAA 3' (Morales, 2009; Morales, Vila \& Poulin, 2011). The PCR reaction was standardized in a total volume of $25 \mu \mathrm{l}: 2.5 \mu \mathrm{l} 10 \mathrm{X}$ PCR buffer $(50 \mathrm{mM} \mathrm{KCl}, 10 \mathrm{mM}$ Tris- $\mathrm{HCl}, \mathrm{pH}$ 8.0), $2 \mu \mathrm{MgCl} 250 \mathrm{mM}, 2 \mu \mathrm{l}$ of each primer $10 \mathrm{pm} / \mu 1,2 \mu \mathrm{l} \mathrm{dNTP} 2.5 \mathrm{mM}, 0.5 \mu 1 \mathrm{Taq}$ (Invitrogen), $9 \mu 1$ ultrapure water, $1 \mu \mathrm{l}$ DMSO and $4 \mu \mathrm{l}$ of $10 \mathrm{ng} / \mu 1$ DNA.

The PCR cycle consisted of an initial denaturation for $4 \mathrm{~min}$ at $94^{\circ} \mathrm{C}$, followed by 38 cycles of $45 \mathrm{sec}$ at $94^{\circ} \mathrm{C}, 90 \mathrm{sec}$ at $66^{\circ} \mathrm{C}\left(65.2^{\circ} \mathrm{C}\right.$ for Caquena samples, $63.5^{\circ} \mathrm{C}$ for Colpa samples) and $90 \mathrm{sec}$ at $72{ }^{\circ} \mathrm{C}$, with a final extension of $10 \mathrm{~min}$ at $72^{\circ} \mathrm{C}$. PCR products were visualized in $2 \%$ agarose gel stained with SYBR. Amplification products were sent for sequencing to Macrogen Inc. (South Korea). D-loop sequences were aligned, edited and assembled using the Proseq v.2.9.1 program (Filatov, 2002) and Bioedit Sequence alignment editor version 7.2.6 software (Hall, 1999).

Using the mitochondrial D-loop control region, genetic diversity indices were calculated for each locality, including number of haplotypes (K), number of polymorphic sites (S), haplotype diversity $(\mathrm{H})$, average number of differences between pairs of sequences $(\Pi)$ and nucleotide diversity $(\pi)$ in DNA Sequence Polymorphism (DnaSp) software version 5.10.01 (Librado \& Rozas, 2009).

To estimate the level of genetic differentiation between pairs of locations we used the $\Phi_{\mathrm{ST}}$ and $\mathrm{F}_{\mathrm{ST}}$ indices in Arlequin software version 3.5.1 (Excoffier, 2010). The significance of $\mathrm{F}_{\mathrm{ST}}$ and $\Phi_{\mathrm{ST}}$ was tested with 10,000 permutations. To evaluate the existence of phylogeographic structure $\mathrm{G}_{\mathrm{ST}}$ (genetic differentiation) and $\mathrm{N}_{\mathrm{ST}}$ (genetic differentiation considered as genetic distance between haplotypes) values were calculated in PERMUT version 2.0 (Pons \& Petit, 1996; Burban et al., 1999) based on the null hypothesis $\mathrm{G}_{\mathrm{ST}}=\mathrm{N}_{\mathrm{ST}}$. If $\mathrm{N}_{\mathrm{ST}}$ is significantly greater than $\mathrm{G}_{\mathrm{ST}}$ this hypothesis is rejected and suggests the existence of phylogeographic structure. A total of 1,000 permutations to determine significance of this comparison were tested in the same software. 
227 Coalescent analysis was based on single locus; the genealogical relationships between

228 haplotypes were graphed by constructing a haplotype network using the median-joining

229 algorithm implemented in the Network version 4.501 software (Bandelt et al., 1999). To detect

230 possible deviations from mutation-drift equilibrium (under the Wright-Fisher model) that could

231 indicate population expansions or bottlenecks, in each genetic group Tajima and Fu tests were

232 performed under assumption of neutrality in Dnasp version 5.10.01 (Librado \& Rozas, 2009).

233 Although both account for the occurrence of demographic pressures in the past, their predictive

234 power varies according to the type of event (Ramírez-Soriano et al., 2008), so the results of the

235 tests were compared.

236 For demographic analysis, a mutational rate was estimated. Considering the evidence of "time 237 dependency" of mitochondrial DNA evolutionary rates in freshwater fishes (Ho et al., 2005; Ho 238 \& Larson, 2006; Burridge et al., 2008; González-Wevar et al., 2015), the substitution rate for the 239 demographic analysis of Orestias was estimated using the phylogenetic relationships and 240 divergence times on BEAST software version 1.8.4 (Drummond, Suchard, Xie \& Rambaut, 241 2012). A Bayesian framework which allowed for variable divergence time estimations among 242 lineages was used and an uncorrelated relaxed clock with a lognormal distribution model was 243 used as prior based on the relevance of evolutionary rates. We used a total of 254 sequences 244 where 61 was from of Chilean Orestias phylogeny on Vila et al. (2013) with GenBank accession 245 numbers JX134506.1- JX134566.1 and 117 from Guerrero et al. (2017) with the GenBank 246 accession numbers KX498242.1- KX498358.1. We added 76 new sequences from this work. 247 Despite not having fossil record, the analysis was calibrated according geological/ hydrological 248 events that modified the aquatic systems of Altiplano (Supplemental data S2). We used three 249 different models to evaluate past demographic changes. First, mismatch distribution and 250 demographic expansion values were calculated based on the instant growth model of Schneider 251 \& Excoffier (1999) available in Arlequin; Tau $\tau$ is the time the expansion began measured in 252 mutational steps, $\theta 0$ corresponds to $2 \mathrm{~N} \mu, \mathrm{Ne} 0$ refers to the theoretical effective population size

253

254

255

256

257

258

259

260

261

262

263

264

265

266

267

before expansion and $\theta 1$ is the effective population size after expansion. Second, we reconstructed the demographic history of each population using (LAMARC) version 2.1.9 (Kuhner, 2006). This program constructs coalescence trees using maximum likelihood; several population parameters are estimated from these trees. The growth rate is $g$ and the values of $\theta 0$ and $\theta t$ indicate the population sizes at present and at time $t$, respectively. Finally, we infer demographic history of populations performing a Bayesian Skyline analysis available on BEAST program version 1.10.4 (Suchard et al., 2018) with an uncorrelated relaxed clock and a random starting tree. The analysis was performed with MCMC of 10,000,000-2,000,000 iterations depending on the number of sequences analyzed with $10 \%$ as a burn-in. The value of the estimated mutational rate was assumed as the "mean" value of the uncorrelated relaxed clock model with a standard deviation of $10 \%$ on priors setting. The results were analyzed using Tracer program version 1.7.2 (Rambaut et al., 2018) where a Bayesian skyline plot was constructed. Bayesian skyline plots shows changes through the time of the product of effective population size $(\mathrm{Ne})$ and generation time $(\mathrm{t})$.

\section{Nuclear DNA}

Peer] reviewing PDF | (2020:10:53879:3:0:NEW 7 Jul 2021) 
268 We amplified eight microsatellite loci, originally optimized in O. agassii of Bolivia by Esquer 269 Garrigos et al. (2011) (Table 2). Amplification of the loci was performed in three mixes 270 according to affinity of alignment temperatures, they were MIX1: A106, B1 and C102; MIX2: 271 A116, B104, C105 and D110; MIX3: B103. The PCR reaction volume was standardized at 10 $272 \mu 1: 2 \mu 15 X$ PCR Buffer (50mM KCl, 10mM Tris-HCL, pH 8.0), $0.9 \mu 125 \mathrm{mM} \mathrm{MgCl} 2,1 \mu 1$ $2730.1 \mathrm{mg} / 1 \mathrm{BSA}, 0.5 \mu 1$ of each $50 \mathrm{pm} / \mathrm{ul}$ primer, $0.8 \mu 12.5 \mathrm{mM}$ dNTP, $3.2 \mu 1$ ultrapure water, $0.1 \mu 1$ 274 Taq (according to MIX number) and $1 \mu 150 \mathrm{ng} / \mathrm{ul}$ DNA. Multiplex PCR Master Mix (QIAGEN) 275 was used for MIX 1 and 2 and Taq platinum (ThermoFisher Scientific ${ }^{\circledR}$ ) was used for MIX 3. 276 The PCR program was different for each MIX used, with annealing temperatures that varied 277 between $51-60{ }^{\circ} \mathrm{C}$ (see Table S3). Amplification products were sent for genotyping to Macrogen 278 Inc. (South Korea). The genotyping results were processed using GeneMarker version 2.6.3 279 program (SoftGenetics). To review and correct the existence of null alleles, stuttering errors and 280 alleles with large peaks, Micro-Checker version 2.2.3 program (Van Oosterhout et al., 2004) was 281 used.

282 Allele frequencies observed, heterozygosity (Ho) and expected heterozygosity (He) were 283 calculated for each locus. $\mathrm{F}_{\text {IS }}$ was calculated and its significance was tested with 10,000 284 permutations in Genetix version 4.05.2 (Belkhir et al., 2004). To evaluate genetic and 285 phylogeographic structure, $\mathrm{F}_{\mathrm{ST}}$ between pairs of locations were determined in Arlequin version 286 3.5.1 (Excoffier, 2010); their significance was evaluated by 10,000 permutations. A reassignment 287 test was performed in the different genetic groups to assess the agreement between the 288 assignment or exclusion of reference populations as a possible origin of the individuals based on 289 multilocus genotypes (Paetkaud et al., 1995) in the Geneclass 2 software (Piry et al., 2004). 290 Finally, a Bayesian analysis was performed to infer the number of genetic groups $(\mathrm{K})$ of the 291 individual genotypes in Structure version 2.2 (Evanno et al., 2005), using the parameters cited in 292 Guerrero-Jiménez et al. (2017).

293

294

295

296

297

298

299

300

301

302

303

304

305

\section{Results}

\section{Mitochondrial DNA}

\subsection{Genetic diversity}

195 sequences of 815 bp in 9 locations were obtained. The genetic diversity indices are shown in Table 3. The Ancuta population showed only one haplotype, with the lowest diversity of all analyzed localities. The Umaqui population presented the highest values of nucleotide and haplotype diversity.

\subsection{Differentiation among populations and haplotype characterization}

$\mathrm{F}_{\mathrm{ST}}$ and $\Phi_{\mathrm{ST}}$ analyses (Table 4$)$ show highly significant differentiation $(\mathrm{p}<0.0001)$, except for the Lauca-Chuviri and Misituni-Chuviri comparisons, whose values were not significant. The haplotype network showed an extended pattern with some haplotypes shared between Caquena and LNP populations. 
306 A clear differentiation is observed between the locations of LNP and Ancuta-Paquisa, however, 307 they share a star-like net form (Fig. 2).

308 As found by Guerrero-Jiménez et al. (2017), the mismatch distribution was unimodal for the 309 LNP localities and also for Paquisa (Fig. 3); this is consistent with the results of the indexes of

310 Tajima and $\mathrm{Fu}$, which were significant and negative for all these locations (Paquisa Fu: -2.14,

$311 \mathrm{p}<0.01$ Tajima: $-2.80, \mathrm{p}<0.02$; LNP Fu: -2.27, $\mathrm{p}<0.01$ /Tajima: $-4.3, \mathrm{p}<0.02$ ), indicating evidence

312 of demographic expansion.

313 The mismatch distribution for Caquena sub-basin locations was multimodal (Fig. 3), and the

314 Tajima and Fu indexes were positive but not significant (data not shown). It was not possible to

315 perform this analysis for Ancuta, because only one haplotype was found. Considering this result, 316 the models of demographic history of populations were tested only on those locations where

317 evidence of population expansion was found.

318 The permutation analysis to evaluate the existence of phylogeographic structure showed a GST

319 value lower than NST but it was not significant ( $p>0.05)$ therefore it can be inferred that there is 320 no phylogeographic structure between sub-basins.

321

322

323

324

325

326

327

328

329

330

331

332

333

334

335

336

337

338

339

340

341

342

343

344

345

\subsection{Demographic analysis}

Corresponding to parameters estimated by the demographic analyses performed, the calculation of the expansion time in years was based on numbers of mutational steps with a mutational rate of $3.99 \%$ per million years (Supplemental data S2).

According to the model of Schneider and Excoffier (1999) the time since the expansion for Paquisa is $14,800 \mathrm{yBP}$, while in the Kuhner model (2006), it corresponds to 9,250 yBP (Table 5). The times estimated since expansion for LNP locations were 5,245y BP and 7,750 yBP respectively.

Regarding the Bayesian skyline analysis performed, the mean of the uncorrelated relaxed clock model was, as mentioned, the value of the estimated rate per millions of years $\left(3.99^{*} 10^{-6}\right)$ and the prior distribution was computed as normal with an interval of $3.136^{*} 10^{-6}-4.664 * 10^{-6}$. The Bayesian Skyline Plots of populations showed the same patterns found on mismatch distributions. While historical $\mathrm{N}_{\mathrm{et}}$ of Caquena sub-basin populations Umaqui, Caquena and Colpa were stable over time with signals of population decline towards to recent time, Paquisa and LNP populations showed an expansion signal that began approximately 2.5-3 My BP for Paquisa population and 15-20,000 yBP for LNP populations. For Umaqui and Paquisa, the TMRCA was estimated approximately at $1 \mathrm{My}$ BP while for Caquena, Colpa and LNP was of 2.8My BP, 4My BP and 13,000 yBP respectively (Fig.4).

\section{Nuclear DNA}

\subsection{Genetic diversity}

Multilocus genotypes of 207 individuals in 9 locations were obtained. The analysis of the data with Micro-checker did not find null alleles, stuttering errors or significant deviations from the Hardy-Weinberg equilibrium. In addition, no linkage imbalances were found among loci within 
346 populations after applying the Bonferroni correction. Descriptive indices of genetic diversity are 347 shown in Table 6.

348 As was observed on mtDNA diversity, Ancuta showed lowest values in all the indexes analyzed. $349 \mathrm{~F}_{\text {IS }}$ showed non-significant values in almost all the localities except for Misituni, where it was 350 positive and significant.

351

352

353

354

355

356

357

358

359

360

361

362

363

364

365

366

367

368

369

370

371

372

373

374

375

376

377

378

379

380

381

382

383

\subsection{Differentiation among populations}

$\mathrm{F}_{\mathrm{ST}}$ analyses (Table 7) indicated that the comparisons of locations between and within sub-basins show highly significant differentiation values $(\mathrm{p}<0.0001)$ except for the Copapujo-Chuviri and Lauca-Misituni pairs, both from the Lauca sub-basin, where the values of the index were not significant.

Individual assignment (GeneClass) to the populations delimited by pairwise $\mathrm{F}_{\mathrm{ST}}$ analysis (Fig. 5), showed a high percentage (75\%) of correct assignments to their reference location. Caquena and Paquisa had $100 \%$ correct assignments, while the localities of LNP show a great percentage of individuals that were not reassigned to their reference location.

\subsection{Genetic structure and cluster assignment}

Bayesian analysis (Structure) to infer the number of genetic groups $(K)$ of the individual genotypic data is shown in Fig. 6, where it was obtained, in which the appropriate number of genetic groups based on $\mathrm{Ln}(\mathrm{P})$ of the sample is five, formed by Umaqui and Colpa; Caquena; Chuviri and Copapujo; Lauca and Misituni and finally a group with Ancuta and Paquisa.

\section{Discussion}

It has been proposed that the uplift of the altiplano occurred mainly during the Miocene-Pliocene period, whose greatest height would have been reached at the end of the Pliocene ( 5-2 MyBP) (Villwock, 1983; Muñoz \& Charrier, 1996; Lamb \& Davis, 2003). In this period, the Caquena and Lauca sub-basins would have risen above 4000 masl. During this process, together with high tectonic activity, atmospheric and oceanic circulation, it would have promoted hyper-arid climatic conditions in the area (Lamb \& Davis, 2003), even when highly variable rainfall regimes are reported (Feitl et al., 2019). Our results showed an expanded haplotype network, with some shared haplotypes between Caquena and LNP populations, which suggests the existence of an ancient lineage with presence in both Caquena and Lauca sub-basins. Individuals of this ancient population of Orestias would have colonized the different limnic systems of the sampled area where the variation in water levels given by the alternation between wet and dry periods would have allowed the sporadic connection of some of them. During the arid periods, isolation, local adaptation and genetic differentiation were promoted, while the wet periods facilitated gene flow (Moreno et al., 2007). Additionally, local pressures like volcanism and anthropic activity would have had a differentiated effect on localities over time (Fig. 7).

\section{Caquena sub-basin}


384 The Caquena sub-basin area is covered by wetlands (bofedales) formed by cushion plants and

385

386

387

388

389

390

391

392

393

394

395

396

397

398

399

400

401

402

403

404

405

406

407

408

409

410

411

412

413

414

415

416

417

418

419

420

421

422

423

other azonal vegetation; several water courses flow in different directions that may or may not discharge into a main course. Pollen record studies of Domic et al. (2018) show that these characteristics have been present at least since $1400 \mathrm{yBP}$ and could have been promoted by human activity since $2000 \mathrm{yBP}$; using the land to maintain grazing areas and water availability would have encouraged humans to maintain them and expand them across the area. The ashes found in cores indicate that volcanism did not have a significant effect on the local vegetation community, which remained stable over $7000 \mathrm{yBP}$. When the level of water rises, this landscape characteristic allows the rapid connection for a wide area and facilitates the exchange of biota, which would have allowed it to maintain effective migrants of Orestias over time. Results of Fu and Tajima indexes were positive but not significant. Therefore, no evidence of demographic expansion could be probed. However, the multimodal distribution of differences between pairs of sequences of populations of Caquena sub-basin, the Bayesian skyline plots and network results are coherent with those of populations that have remained stable over time (Slatkin \& Hudson, 1991; Harpending et al., 1993). This homogenization process may continue to occur today, given the seasonal wet variation within the year.

\section{Lauca sub-basin}

The collapse of the Parinacota volcano $(8,800 \mathrm{yBP})$ is cited as one of the principal modifiers of the Lauca sub-basin area during the Pleistocene-Holocene ages; it gave origin to varied aquatic systems that remain today. This volcanic event would have had a local effect mainly with two different patches, one that reached approximately a $150 \mathrm{~km} 2$ zone that was buried by an avalanche of debris (Jicha et al., 2015), and another given by the modification of course of the Paleo-Lauca River that changed from northerly to southerly (Sáez et al., 2007), affecting the connectivity of some areas of the sub-basin. It was observed the conformation of two welldefined haplotype groups on the sub-basin, one containing the LNP localities and the other with Ancuta-Paquisa localities, however it is important to highlight that they are inserted on a wider haplotype network sharing genetic diversity with the neighbor Caquena sub-basin. Our results support that, as was demonstrated by Guerrero-Jimenez et al. (2017) on LNP, the fragmentation of hydrological systems, would have restructured the gene flow between the populations of Orestias that inhabit them. Initially by a decrease in the effective size that, due to the effect of genetic drift, decreased the number of haplotypes and later, by a demographic expansion that increased the number of individuals but with genetic diversity remaining scarce. Subject to the generation of new environmental conditions and the ability of populations to respond to them, new genetic diversity would be generated. A star-like pattern was found for the haplotype network of both LNP and Paquisa populations, both had unimodal mismatch distributions and also both showed signals of population expansion on Bayesian skyline plot. However, their starting point of demographic expansion was different. For LNP, the range of estimated dates with both Schneider and Excoffier (1999) and Kuhner model (2006) models were after the date of the volcanic collapse making it more likely that the demographic expansion detected could be

Peer] reviewing PDF | (2020:10:53879:3:0:NEW 7 Jul 2021) 
424 attributable to the geological changes caused by this event. For Paquisa, on the other hand, 425 despite the range of intervals calculated for both models was wider, the date of demographic 426 expansion was rather before the collapse (Table 5). Yet although the timing of population 427 expansion start time estimated by the Bayesian skyline analysis was earlier than that estimated 428 by the other models, all three models agree on Paquisa expansion time would have been earlier 429 than LNP populations. In addition, it is remarkable the high differentiation of $F_{\mathrm{ST}}$ and $\Phi_{\mathrm{ST}}$

430

431

432

433

434

435

436

437

438

439

440

441

442

443

444

445

446

447

448

449

450

451

452

453

454

455

456

457

458

459

460

461

462

463 indexes of Paquisa-Ancuta with all other sampled locations. This high genetic distance seems to respond to an older isolation reached before the change in the course of Lauca River and suggests their haplotypes might have not been constituted as a consequence of the volcanic collapse 8,800 yBP rather it could have been generated together with the uplift of Altiplano 5-2 M yBP (Villwock 1983; Kött, Gaup \& Wörner 1995; Muñoz \& Charrier 1996; Lamb \& Davis 2003).

The reconstruction of geological history of the basin, indicates a shallower northern part and a southern part which houses its oldest deposits. Over this area the existence of closed lake conditions with significant variation on water level has been probed (Feitl et al., 2019). This Lake $(3.7<0.25 \mathrm{MyBP})$, was progressively replaced by rivers and ponds to several terraces fragmented the area by precursors of Lauca River and its tributaries (Kött, Gaupp \& Worner, 1995; Gaupp, Kött \& Worner, 1999). These antecedents suggest that not only the volcanic activity could have effects on the evolutionary history of the Orestias populations and that perhaps in the southern area (Ancuta-Paquisa) of the Lauca sub-basin, events of landscape modifications such as variations in water levels could have had greater incidence on the genetic differentiation of their populations.

\section{A shared history?}

Further analysis is required for the comprehension of Orestias colonization processes across the Altiplano basin, however, this study provides new evidence that contributes to the reconstruction of its evolutionary history.

The geological and climatic variations that occurred after the collapse of the Parinacota volcano, strong volcanic activity 8000-4000 yBP followed by arid and humid periods, gradually generated the arid and warm conditions that prevail today (Placzek, Quade \& Patchett, 2006; Vila et al., 2013) and gave way to the formation of aquatic systems as we know them. This transition process would have increased geographic isolation among the sampled populations, restricting dispersion and promoting genetic diversification associated with local adaptation, which is reflected in the microsatellite results where $\mathrm{F}_{\mathrm{ST}}$ comparisons (Table 7) and reassignment tests (Fig. 5) show similarities between geographically closest localities and the five genetic groups that were identified with the cluster analysis, Caquena, Umaqui-Colpa, Copapujo-Chuviri, Lauca-Misitune and Ancuta-Paquisa (Fig. 6). Nuclear marker analysis results were coherent with those obtained by mitochondrial data. These confirm the scenario of recent diversification and incipient speciation process of Orestias that was described by Guerrero-Jiménez et al. (2017) in Lauca National Park but it shows signs that it is framed on a much older evolutionary history that 
464 points to a shared history of all populations sampled before the conformation of the sub-basins, 465 meaning that what was reported for the LNP would respond to a local disturbance. According to 466 this, we hypothesize that first there was an original widespread population across Caquena and 467 Lauca sub-basins due to variations in the water level and their adaptation to environmental 468 conditions that allowed them to establish. Then this population was subjected to local 469 disturbances that strongly affected the connectivity of some areas like isolation (Ancuta-Paquisa)

470

471

472

473

474

475

476

477

478

479

480

481

482

483

484

485

486

487

488

489

490

491

492

493

494

495

496

497

498

499

500

501

502

503 and fragmentation of habitat but were not significant for others (Caquena sub-basin localities). Finally, the availability of novel habitats with different environmental characteristics resulted in genetic diversification (mainly in LNP). Additionally, we think that the high genetic differentiation found for Ancuta-Paquisa from the rest might be the result of an older event and could be attributed to different factors. One of these explanations could be a border colonization of individuals that would have been carriers of low frequency haplotypes of an ancient population that reach this area and remained isolated even after the collapse of Parinacota volcano.

Finally, it is important to point out that the processes of connection and disconnection between populations would be associated with both past and present environmental conditions, and also that both Caquena and Lauca sub-basins are part of broader hydrological networks connected with Bolivia and Peru, which creates a framework of much greater possibilities when it comes to elucidating the possible routes that would account for the colonization of Orestias through the Altiplano and for the understanding of their diversification processes, thus it would be of great importance to expand these studies to the neighboring basins in Bolivia and Perú.

\section{Implications for conservation}

Altiplano aquatic systems are highly threatened and tend to desiccation and salinization because they are immersed in a desert matrix that intensifies significantly year after year (Demergasso et al., 2010). It is expected that current climatic conditions will be different according to the particularities of the ecosystems and specific places (Sarricolea Espinoza \& Romero Aravena, 2015; Sarricolea Espinoza, Meseguer Ruiz \& Romero Aravena, 2017). These highland aquatic ecosystems are faced with various threats, among which are legal factors derived from the regulatory status that Chile adopted for water resources, the overexploitation of aquifers especially associated with their high use in the mining industry, and water pollution which has created hydric stress throughout the area (IGM, 1983; MMA, 2018). Studies of genetic diversity are key to the development of conservation and management strategies to allow conservation efforts to be directed towards these most vulnerable populations and to be able to recover and maintain them in the long term, minimizing the impacts that anthropic activity could generate on them (MMA, 2018). They are a significant source of knowledge for the understanding of the evolutionary history of species and how they have been related over time.

Despite the fact that they now inhabit separate basins, the Orestias populations of the Caquena and Lauca sub-basins have a shared history and represent different conservation units, whether due to the age of their haplotypes, the genetic diversification processes that continue to occur or 
504 for the uniqueness of their genetic diversity, hosting a relevant gene pool for this genus and 505 maybe not only for it but also of the biodiversity that characterizes the entire area. However, the 506 status of protection of these sub-basins is still in development. While the Caquena sub-basin has 507 been considered in a national plan to protect wetlands that should be fully implemented in 2022 ,

508 Lauca sub-basin is protected by a national park and a national reserve (Fig.1). Even with these 509 measures, during sampling we observed anthropic perturbations inside it such as the extraction of 510 water to moisten the roads and the channeling of water courses for the mining industry,

511 increasing water quality deterioration.

\section{Conclusions}

513 The performed analyzes allowed us to use the information obtained from mitochondrial and 514 nuclear molecular markers to characterize genetic diversity and reconstruct part of the

515 evolutionary history of Orestias in the Caquena and Lauca sub-basins. It was found that although

516 the localities have variable genetic diversity and are differentiated from each other, they share

517 genetic diversity. Our results revealed a scenario where Orestias of Caquena and Lauca sub-

518 basins shared its evolutionary history by the presence of ancient lineages. These groups that 519 would have dispersed throughout this area were affected by local disturbances that fragmented 520 and isolated them. We deduced that geological and hydrological events occurred mainly during 521 Pleistocene-Holocene ages, affected the studied sub-basins differently, and we provide some

522

523

524

525

526

527

528

529

530

531

532

533

534

535

536

537

538

539 genetic evidence about how the collapse of the Parinacota volcano would have had an effect on the Orestias populations closest to its volcanic cone as LNP populations, but it would not have reached the most distant populations, as Ancuta-Paquisa area and Caquena sub-basin. Moreover, our results allowed us to infer that the genetic differentiation processes of the LNP populations are more recent than those occurred in the rest of the sampled localities. Further studies of taxa cohabitant with Orestias would allow contrasting their diversification patterns and strengthen the proposal of genetic and ecological differentiation processes in the Altiplano aquatic ecosystems. Altiplano aquatic ecosystems harbor very unique characteristics of environmental conditions and biodiversity and they face varied types of threats to their conservation and consequently to the taxa that inhabit them. Studies of this type will provide basic information to formulate proposals for conservation and management strategies that guide decision-making regarding their protection.

\section{Acknowledgements}

We would like to thank the Laboratorio de Limnología of the Universidad de Chile for its generous welcome and willingness to carry out this research, the Laboratorio de Ecología Molecular of Universidad de Chile, Laboratorio de Ciencias Biomédicas of the Universidad Autónoma de Chile and the Centro de Biotecnología of Universidad Iberoamericana de Ciencias y Tecnología for their important collaboration in the development of the experimental phase. We 
540 give special thanks to Simón Anguita and Dra. María Cecilia Pardo Gandarillas for their valuable 541 support in molecular features.

542

543 References

544

545

546

547

548

549

550

551

552

553

554

555

556

557

558

559

560

561

562

563

564

565

566

567

568

569

570

571

572

573

574

575

576

Aljanabi SM, Martinez I. 1997. Universal and rapid salt-extraction of high quality genomic DNA for PCR- based techniques. Nucleic Acids Research 25:4692-4693. DOI: 10.1093/nar/25.22.4692.

Arratia G, Vila I, Lam N, Guerrero CJ, Quezada-Romegialli C. 2017. Morphological and taxonomic descriptions of a new genus and species of killifishes (Teleostei: Cyprinodontiformes) from the high Andes of northern Chile. PLoS ONE 12(8): e0181989. DOI: 10.1371/journal.pone.0181989.

Avise JC. 1998. The history and purview of phylogeography: a personal reflection. Molecular Ecology 7: 371-379.

Bandelt HJ, Forster P, Röhl A. 1999. Median-joining networks for inferring intraspecific phylogenies. Mollecular Biology and Evolution 16: 37-48. PMID: 10331250.

Beheregaray LB. 2008. Twenty years of phylogeography: the state of the field and the challenges for the Southern Hemisphere. Molecular Ecology 17(17): 3754-74. DOI: 10.1111/j.1365294X.2008.03857.x.

Belkhir K, Borsa, P., Chikhi, L., Raufaste, N., Bonhomme, F. 2004. GENETIX 4.05, logiciel sous Windows TM pour la génétique des populations. Laboratoire Génome, Populations, Interactions, CNRS UMR 5000, Université de Montpellier II, Montpellier (France).

Bezault E, Mwaiko S, Seehausen O. 2011. Population genomic tests of models of adaptive radiation in Lake Victoria region cichlid fish. Evolution 65(12):3381-97. DOI: 10.1111/j.1558-5646.2011.01417.x.

Burban, C., Petit, R.J., Carcreff, E. \& Jactel, H. 1999. Rangewide variation of the maritime pine bast scale Matsucoccus feytaudi Duc. (Homoptera: Matsucoccidae) in relation to the genetic structure of its host. Molecular Ecology 8: 1593-1602.

Burridge CP, Craw D, Fletcher D, Waters JM. 2008. Geological dates and molecular rates: Fish DNA sheds light on time dependency. Molecular Biology and Evolution 25:624-633. DOI: $10.1093 / \mathrm{molbev} / \mathrm{msm} 271$.

Capobianco A, Friedman M. 2018. Vicariance and dispersal in southern hemisphere freshwater fish clades: a palaeontological perspective. Biological Reviews 94(2):662-699. DOI: 10.1111/brv.12473.

Collado GA, Salinas HF, Méndez MA. 2014. Genetic, morphological, and life history traits variation in freshwater snails from extremely high environments of the Andean Altiplano. Zoological Studies 53:14. DOI: 10.1186/1810-522X-53-14.

PeerJ reviewing PDF | (2020:10:53879:3:0:NEW 7 Jul 2021) 
577

578

579

580

581

582

583

584

585

586

587

588

589

590

591

592

593

594

595

596

597

598

599

600

601

602

603

604

605

606

607

608

609

610

611

612

613

614

615

Collado GA, Vila I, Méndez MA. 2011. Monophyly, candidate species and vicariance in Biomphalaria snails (Mollusca: Planorbidae) from the Southern Andean Altiplano. Zoologica Scripta 40:613-622. DOI: 10.1111/j.1463-6409.2011.00491.x.

Cruz-Jofré F, Morales P, Esquer-Garrigos Y, Vila I, Hugueny B, Gaubert P, Méndez MA. 2014. Taxonomic identity of the forms of Orestias agassii (Teleostei: Cyprinodontidae) from Chile: A morphological comparison with the syntypes of the species of Peru and Bolivia. Gayana 78:25-29. DOI: 10.4067/S0717-65382014000100006.

Cruz-Jofré F, Morales P, Vila I, Esquer-Garrigos Y, Hugueny B, Gaubert P, Poulin E, Méndez MA. 2016. Geographical isolation and genetic differentiation: The case of Orestias ascotanensis (Teleostei: Cyprinodontidae), an Andean killifish inhabiting a highland salt pan. Biological Journal of the Linnean Society 117:747-759. DOI: 10.1111/bij.12704.

Demergasso C, Dorador C, Meneses D, Blamey J, Cabrol N, Escudero L, Chong G. 2010. Prokaryotic diversity pattern in high-altitude ecosystems of the Chilean Altiplano. Journal of Geophysical Research: Biogeosciences 115:1-14. DOI: 10.1029/2008JG000836.

Domic A, Capriles JM, Escobar-Torrez K, Calogero M S, Maldonado A. 2018. Two Thousand Years of Land-Use and Vegetation Evolution in the Andean Highlands of Northern Chile Inferred from Pollen and Charcoal Analyses. Quaternary 1:32. DOI: 10.3390/quat1030032.

Drummond, AJ, Suchard MA, Xie D \& Rambaut A. 2012. Bayesian phylogenetics with BEAUti and the BEAST 1.7. Molecular Biology and Evolution 29: 1969-1973. DOI: 10.1093/molbev/mss075.

Elmer KR, Lehtonen TK, Kautt AF, Harrod C, Meye A. 2010. Rapid sympatric ecological differentiation of crater lake cichlid fishes within historic times . BMC Biology 8,60. DOI: 10.1186/1741-7007-8-60.

Esmaeili H, Asrar T, Gholamifard A. 2018. Cyprinodontid fishes of the world: an updated list of taxonomy, distribution and conservation status (Teleostei: Cyprinodontoidea). Iranian Journal of Ichthyology 5(1): 1-29. DOI: 10.22034/iji.v5i1.267.

Esquer-Garrigos Y. 2013. Multi-scale evolutionary analysis of a high altitude freshwater species flock: diversification of the agassizii complex (Orestias, Cyprinodontidae, Teleostei) across the Andean Altiplano. Thesis. Museum National D'Histoire Naturelle.

Esquer-Garrigos Y, Hugueny B, Ibañez C, Zepita C, Koerner K, Lambourdière J, Couloux A, Gaubert P. 2015. Detecting natural hybridization between two vulnerable Andean pupfishes (Orestias agassizii and $O$. luteus) representative of the Altiplano endemic fisheries. Conservation Genetics 16:717-727. DOI: 10.1007/s10592-015-0695-3.

Esquer-Garrigos Y, Lambourdière J, Ibañez C, Gaubert P. 2011. Characterization of ten polymorphic microsatellite loci in the Andean pupfish Orestias agassizii, with crossamplification in the sympatric O. luteus. Conservation Genetics Resources 3:17-19. DOI: 10.1007/s12686-010-9269-3.

PeerJ reviewing PDF | (2020:10:53879:3:0:NEW 7 Jul 2021) 
616 Evanno, G, Regnaut, S \& Goudet, J. 2005. Detecting the number of clusters of individuals using 617 the software STRUCTURE: A simulation study. Molecular Ecology 14: 2611-2620. DOI: $618 \quad 10.1111 / \mathrm{j} .1365-294 X .2005 .02553 . x$.

619

620

621

622

623

624

625

626

627

628

629

630

631

632

633

634

635

636

637

638

639

640

641

642

643

644

645

646

647

648

649

650

651

Excoffier, L.\& Lischer HE. 2010. Arlequin suite ver 3.5: A new series of programs to perform population genetics analyses under Linux and Windows. Molecular Ecology Resources 10: 564-567. DOI: $10.1111 / \mathrm{j} .1755-0998.2010 .02847 . x$.

Feitl M, Kern AK, Jones A, Fritz SC, Baker PA, Joeckel RM, Salenbien W, Willard D.2019. Paleoclimate of the subtropical Andes during the latest Miocene, Lauca Basin, Chile. Palaeogeography, Palaeoclimatology, Palaeoecology 534. DOI: 10.1016/j.palaeo.2019.109336

Filatov DA. 2002. Proseq: A software for preparation and evolutionary analysis of DNA sequence data sets. Molecular Ecology Notes 2:621-624. DOI: 10.1046/j.1471-8278 .2002.00313.x.

Frankham R. 2005. Genetics and extinction. Biological Conservation 126:131-140. DOI: 10.1016/j.biocon.2005.05.002.

Gaupp R, Kött A, Wörner G. 1999. Palaeoclimatic implications of Mio-Pliocene sedimentation in the high-altitude intra-arc Lauca Basin of northern Chile. Palaeogeography, Palaeoclimatology, Palaeoecology,151: 79-100. DOI: 10.1016/S0031-0182(99)00017-6.

Giralt S, Moreno A, Bao R, Sáez A, Prego R, Valero-Garcés BL, Pueyo JJ, González-Sampériz P, Taberner C. 2008. A statistical approach to disentangle environmental forcings in a lacustrine record: The Lago Chungará case (Chilean Altiplano). Journal of Paleolimnology 40:195-215. DOI: 10.1007/s10933-007-9151-9.

González-Wevar CA, Salinas P, Hüne M, Segovia NI, Vargas-Chacoff L, Astorga M, Cañete JI, Poulin E.2015. Phylogeography in Galaxias maculatus (Jenyns, 1848) along Two Biogeographical Provinces in the Chilean Coast. PLoS ONE 10(7): e0131289. DOI:10.1371/journal.pone.0131289.

Guerrero-Jiménez CJ, Peña F, Morales P, Méndez M, Sallaberry M, Vila I, Poulin E. 2017. Pattern of genetic differentiation of an incipient speciation process: The case of the high Andean killifish Orestias. PLoS ONE 12(2): e0170380. DOI: 10.1371/journal.pone. 0170380 .

Guerrero-Jiménez CJ, Poulin E, Méndez MA, Vila I. 2015. Caracterización trófica de Orestias ( Teleostei : Cyprinodontidae) en el Parque Nacional Lauca. Gayana (Concepción) 79:18-25.

Hall, T.A. 1999. BioEdit: a user-friendly biological sequence alignment editor and analysis program for Windows 95/98/NT. Nucleic Acids Symposium Series 41:95-98.

Harpending HC, Sherry ST, Rogers AR, Stoneking M. 1993. The Genetic Structure of Ancient Human Populations. Current Anthropology 34:483-496. DOI: 10.1086/204195. 
652 Hickerson MJ, Carstens BC, Cavender-Bares J, Crandall KA, Graham CH, Johnson JB, Rissler

653 L, Victoriano PF, Yoder AD. 2010. Phylogeography's past, present, and future: 10 years

654

655

656

657

658 after Avise, 2000. Molecular Phylogenetics and Evolution 54(1):291-301. DOI: 10.1016/j.ympev.2009.09.016.

Ho SYW, Larson G. 2006. Molecular clocks: When times are a-changin'. Trends in Genetics 22:79-83. DOI: 10.1016/j.tig.2005.11.006.

659

660

661

Ho SYW, Phillips MJ, Cooper A, Drummond AJ. 2005. Time dependency of molecular rate estimates and systematic overestimation of recent divergence times. Molecular Biology and Evolution 22:1561-1568. DOI: 10.1093/molbev/msi145.

662

663

664

665

666

667

668

669

670

671

672

673

674

675

676

677

678

679

680

681

682

683

684

685

686

687

688

689

690

691

Instituto Geográfico Militar (IGM). 1983. Geografía de Chile TOMO III: Biogeografía por Victor Quintanilla Pérez, Santiago .

Isacks BL. 1988. Uplift of the central Andean Plateau and bending of the Bolivian Orocline. Journal of Geophysical Research 93:3211-3231. DOI: 10.1029/JB093iB04p03211.

Jicha BR, Laabs BJC, Hora JM, Singer BS, Caffee MW. 2015. Early Holocene collapse of Volcán Parinacota, central Andes, Chile : Volcanological and paleohydrological consequences. Geological Society of America Bulletin 127:1681-1688. DOI: 10.1130/B31247.1.

Katongo C, Koblmüller S, Duftner N, Makasa L, Sturmbauer C. 2005. Phylogeography and speciation in the Pseudocrenilabrus philander species complex in Zambian Rivers. Hydrobiologia 542: 221-233. DOI: 10.1007/s10750-004-1389-x.

Kocher T. 2004. Adaptive evolution and explosive speciation: the cichlid fish model. Nature Reviews Genetics 5: 288-298. DOI: 10.1038/nrg1316.

Kornfield I, Smith PF. 2000. African Cichlid Fishes: Model Systems for Evolutionary

Biology . Annual Review of Ecology and Systematics 31(1):163-96. DOI: 10.1146/annurev.ecolsys.31.1.163.

Kött A, Gaupp R, Wörner G. 1995. Miocene to recent history of the western Altiplano in northern Chile revealed by lacustrine sediments of the Lauca basin $\left(18^{\circ} 15^{\prime}-18^{\circ} 40^{\prime} \mathrm{S} / 69^{\circ} 30^{\prime}\right.$ $\left.69^{\circ} 05^{\prime} \mathrm{W}\right)$. Geologische Rundschau 84:770-780. DOI: 10.1007/s005310050039.

Kuhner, M.K. 2006. LAMARC 2.0: maximum likelihood and Bayesian estimation of population parameters. Bioinformatics 22(6): 768-770. DOI: 10.1093/bioinformatics/btk051.

Lamb, S \& Davis P. 2003. Cenozoic climate change as a possible cause for the rise of the Andes. Nature 425: 792-797. DOI: 10.1038/nature02049.

Lambrinos JG, Kleier CC, Rundell PW. 2006. Plant community variation across a puna landscape in the Chilean Andes. Revista Chilena de Historia Natural 79:233-243. DOI: 10.4067/S0716-078X2006000200009. 
692 Librado, P. \& Rozas, J. 2009. DnaSP v5: a software for comprehensive analysis of DNA

693

694

695

696

697

698

699

700

701

702

703

704

705

706

707

708

709

710

711

712

713

714

715

716

717

718

719

720

721

722

723

724

725

726

727 polymorphism data. Bioinformatics 25(11): 1451-1452. DOI: 10.1093/bioinformatics/btp187.

Lüssen A, Falk TM, Villwock W. 2003. Phylogenetic patterns in populations of Chilean species of the genus Orestias (Teleostei: Cyprinodontidae): Results of mitochondrial DNA analysis. Molecular Phylogenetics and Evolution 29:151-160. DOI: 10.1016/S1055-7903(03)000770 .

Maldonado E, Hubert N, Sagnes P, De Mérona B. 2009. Morphology-diet relationships in four killifishes (Teleostei, Cyprinodontidae, Orestias) from Lake Titicaca. Journal of Fish Biology 74:502-520. DOI: 10.1111/j.1095-8649.2008.02140.x.

Marques DA, Meier JI, Seehausen O. 2019. A Combinatorial View on Speciation and Adaptive Radiation. Trends in Ecology \& Evolution 34(6): 531-544. DOI:10.1016/j.tree.2019.02.008.

Márquez-García M, Vila I, Hinojosa LF, Méndez MA, Carvajal JL, Sabando MC. 2009. Distribution and seasonal fluctuations in the aquatic biodiversity of the southern Altiplano. Limnologica 39:314-318. DOI: 10.1016/j.limno.2009.06.007.

Mehner T, Pohlmann K, Elkin C, Monaghan MT, Nitz B, Freyhof J. 2010. Genetic population structure of sympatric and allopatric populations of Baltic ciscoes (Coregonus albula complex, Teleostei, Coregonidae). BMC Evolutionary Biology 10: 85. DOI: 10.1186/14712148-10-85.

Ministerio del Medio Ambiente (MMA). 2018. Biodiversidad de Chile. Patrimonio y desafíos. Santiago.

Morales P. 2018. Patrones de divergencia genómica en diferentes etapas del continuo de especiación en el género Orestias ( Teleostei; Cyprinodontidae). Thesis, Universidad de Chile.

Morales P, Vila I, Poulin E. 2011. Genetic structure in remnant populations of an endangered cyprinodontid fish, Orestias ascotanensis, endemic to the Ascotán salt pan of the Altiplano. Conservation Genetics 12:1639-1643. DOI: 10.1007/s10592-011-0245-6.

Moreno A, Giralt S, Valero-Garcés B, Sáez A, Bao R, Prego R, Pueyo JJ, González-Sampériz P, Taberner C. 2007. A 14 kyr record of the tropical Andes: The Lago Chungará sequence ( $18^{\circ} \mathrm{S}$, northern Chilean Altiplano). Quaternary International 161:4-21. DOI: 10.1016/j.quaint.2006.10.020.

Muñoz N, Charrier R. 1996. Uplift of the western border of the Altiplano on a west-vergent thrust system, Northern Chile. Journal of South American Earth Sciences 9:171-181. DOI: 10.1016/0895-9811(96)00004-1.

Niemeyer H. 1982. Hoyas hidrográficas de Chile: Primera Región. Dirección General de Aguas, Ministerio de Obras Públicas, Santiago. 
728

729

730

731

732

733

734

735

736

737

738

739

740

741

742

743

744

745

746

747

748

749

750

751

752

753

754

755

756

757

758

759

760

761

762

763

Northcote TG. (2000). Ecological interactions among an Orestiid (Pisces: Cyprinodontidae) species flock in the littoral zone of Lake Titicaca. In: Rossiter, A, Kawanabe, H, eds. Ancient Lakes: Biodiversity, Ecology and Evolution, Academic Press: 399-420.

Paetkaud D, Calvert W, Stirling I \& Strobeck C. 1995. Microsatellite analysis of population structure in Canadian polar bears. Molecular Ecology 4:347-354. DOI: 10.1111/j.1365294x.1995.tb00227.x.

Parenti LR. 1981. A phylogenetic and biogeographic analysis of cyprinodontiform fishes (Teleostei, Atherinomorpha). Bulletin of the American Museum of Natural History 168:335357.

Parenti LR. 1984a. A taxonomic revision of the Andean killifish genus Orestias (Cyprinodontiformes, Cyprinodontidae). Bulletin of the American Museum of Natural History 178:107-214.

Parenti LR. 1984b. Biogeography of the Andean Killifich genus Orestias with comments on the species flock concept. In: Echuelle AA, Kornfield I, eds. Evolution of Fish Species Flocks Maine: University of Maine Press Orono 85-92.

Parker A, Kornfield I. 1995. Molecular Perspective on Evolution and Zoogeography of Cyprinodontid Killifishes (Teleostei, Atherinomorpha). Copeia 1995:8-21. DOI: $10.2307 / 1446795$.

Peña F. 2010. Diferenciación genética en poblaciones de Orestias laucaensis (Arratia,1982) en el Altiplano Sur-Chile. Thesis, Universidad de Chile.

Placzek, C., Quade, J. \& Patchett, P.J. 2006. Geochronology and stratigraphy of late Pleistocene lake cycles on the southern Bolivian Altiplano: Implications for causes of tropical climate change. Geological Society of America Bulletin 118: 515-532. DOI: 10.1130/B25770.1.

Piry, S., Alapetite, A., Cornuet, J.M., Paetkau, D., Baudouin, L. \& Estoup, A. 2004 GeneClass2: A Software for Genetic Assignment and First-Generation Migrant Detection. Journal of Heredity 95(6): 536-539. DOI: 10.1093/jhered/esh074.

Pohl M, Milvertz FC, Meyer A, Vences M. 2015. Multigene phylogeny of cyprinodontiform fishes suggests continental radiations and a rogue taxon position of Pantanodon. Vertebrate Zoology 65:37-44.

Pons, O. \& Petit, R. 1996. Measuring and testing genetic differentiation with ordered versus unordered alleles. Genetics 144(3): 1237-1245.

Ramírez-Soriano A, Ramos-Onsins SE, Rozas J, Calafell F, Navarro A. 2008. Statistical power analysis of neutrality tests under demographic expansions, contractions and bottlenecks with recombination. Genetics 179:555-567. DOI: 10.1534/genetics.107.083006.

Rambaut A, Drummond AJ, Xie D, Baele G and Suchard MA. 2018. Posterior summarisation in Bayesian phylogenetics using Tracer 1.7. Systematic Biology. syy032. 
765

766

767

768

769

770

771

772

773

774

775

776

777

778

779

780

781

782

783

784

785

786

787

788

789

790

791

792

793

794

795

796

797

798

799

800

801

Rissler LJ. 2016. Union of phylogepgraphy and landscape genetics. Proceedings of the National Academy of Sciences 113 (29) 8079-8086. DOI: 10.1073/pnas.1601073113.

Rubinoff D, Reil JB, Osborne KH, Gregory CJ, Geib SM, Dupuis JR. 2020. Phylogenomics reveals conservation challenges and opportunities for cryptic endangered species in a rapidly disappearing desert ecosystem. Biodiversity and Conservation 29: 2185-2200. DOI: 10.1007/s10531-020-01968-w.

Rundel PW, Palma B. 2000. Preserving the unique puna ecosystems of the Andean Altiplano: A descriptive account of Lauca National Park, Chile. Mountain Research and Development 20(3):262-271. DOI: 10.1659/0276-4741(2000)020[0262:PTUPEO]2.0.CO;2

Sáez A, Valero-Garcés BL, Moreno A, Bao R, Pueyo JJ, González-Sampériz P, Giralt S, Taberner C, Herrera C, Gibert RO. 2007. Lacustrine sedimentation in active volcanic settings: The Late Quaternary depositional evolution of Lake Chungará (northern Chile). Sedimentology 54:1191-1222. DOI: 10.1111/j.1365-3091.2007.00878.x.

Salazar, C. 1997. Hidrología del sector altiplánico chileno en Charrier, R., Aceituno, P., Castro, M., Llanos, A. \& Raggi, L. El altiplano. Ciencia y conciencia en los andes. Actas del II Simposio Internacional de Estudios Altiplánicos. Universidad de Chile, Vicerrectoría académica y estudiantil, Departamento de posgrado y postítulo. Arica, Chile.

Salzburger W, Mack T, Verheyen E, Meyer A. 2005. Out of Tanganyika: Genesis, explosive speciation, key-innovations and phylogeography of the haplochromine cichlid fishes. $B M C$ Evololutive Biology 5: 17. DOI: 10.1186/1471-2148-5-17.

Sarricolea Espinoza P, Meseguer Ruiz Ó, Romero Aravena H. 2017. Tendencias de la precipitación en el norte grande de chile y su relación con las proyecciones de cambio climático. Dialogo Andino 54:41-50. DOI: 10.4067/S0719-26812017000300041.

Sarricolea Espinoza P, Romero Aravena H. 2015. Variabilidad y cambios climáticos observados y esperados en el Altiplano del norte de Chile. Revista de Geografia Norte Grande 62:169183. DOI: $10.4067 / \mathrm{S} 0718-34022015000300010$.

Setiamarga DHE, Miya M, Yamanoue Y, Mabuchi K, Satoh TP, Inoue JG, Nishida M. 2008. Interrelationships of Atherinomorpha (medakas, flyingfishes, killifishes, silversides, and their relatives): The first evidence based on whole mitogenome sequences. Molecular Phylogenetics and Evolution 49:598-605. DOI: 10.1016/j.ympev.2008.08.008.

Schneider, S. \& Excoffier, L. 1999. Estimation of past demographic parameters from the distribution of pairwise differences when the mutation rates vary among Sites: Application to human mitochondrial DNA. Genetics 152(3): 1079-1089.

Scott SA. 2010. Sistemática y filogenia de Orestias del complejo agassizii (Teleostei: Cyprinodontidae) de la Puna. Thesis, Universidad de Chile.

PeerJ reviewing PDF | (2020:10:53879:3:0:NEW 7 Jul 2021) 
802 Scott S, Dorador C, Oyanedel JP, Tobar I, Hengst M, Maya GI, Harrod C, Vila I. 2015.

803 Microbial diversity and trophic components of two high altitude wetlands of the Chilean

804 Altiplano. Gayana (Concepción) 79(1):45-56. DOI: 10.4067/S0717-65382015000100006.

805

806

807

808

809

810

811

812

813

814

815

816

817

818

819

820

821

822

823

824

825

826

827

828

829

830

831

832

833

834

835

Slatkin M, Hudson RR. 1991. Pairwise Comparisons of Mitochondrial DNA Sequences in Stable and Exponentially Growing Populations. Genetics 129(2):555-562.

Suchard MA, Lemey P, Baele G, Ayres DL, Drummond AJ \& Rambaut A. 2018. Bayesian phylogenetic and phylodynamic data integration using BEAST 1.10. Virus Evolution 4, vey016. DOI:10.1093/ve/vey016

Takuno S, Miyagi R, Onami JI, Takahashi-Kariyazono S, Sato A, Tichy H, Nikaido M, Aibara M, Mizoiri S, Mrosso HDJ, Mzighani SI, Okada N, Terai Y. 2019. Patterns of genomic differentiation between two Lake Victoria cichlid species, Haplochromis pyrrhocephalus and H. sp. 'macula'. BMC Evolutionary Biology 19: 68. DOI:10.1186/s12862-019-1387-2.

Van Oosterhout C, Hutchinson WF, Wills DPM \& Shipley P. 2004. MICROCHECKER: software for identifying and correcting genotyping errors in microsatellite data. Molecular Ecology Notes 4: 535-538. DOI: 10.1111/j.1471-8286.2004.00684.x.

Vila I, Méndez MA, Scott S, Morales P, Poulin E. 2007. Threatened fishes of the world: Orestias ascotanensis Parenti, 1984 (Cyprinodontidae). Environmental Biology of Fishes 80:491492. DOI: $10.1007 / \mathrm{s} 10641-006-9150-0$.

Vila I, Morales P, Scott S, Poulin E, Véliz D, Harrod C, Méndez MA. 2013. Phylogenetic and phylogeographic analysis of the genus Orestias (Teleostei: Cyprinodontidae) in the southern Chilean Altiplano: The relevance of ancient and recent divergence processes in speciation. Journal of Fish Biology 82:927-943. DOI: 10.1111/jfb.12031.

Vila I, Pardo R, Scott S. 2007. Freshwater fishes of the Altiplano. Aquatic Ecosystem Health and Management 10:201-211. DOI: 10.1080/14634980701351395.

Villwock W. 1983. El género Orestias y su Evolución en el Altiplano del Perú y Bolivia. Informe final IX Claz, Perú, 59-66.

Vrtílek M, Žák J, Blažek R, Polačik M, Cellerino A, Reichard M. 2018. Limited scope for reproductive senescence in wild populations of a short-lived fish. Science of Nature 105(1112), 68. DOI: 10.1007/s00114-018-1594-5.

Yi X-G, Chen J, Zhu H, Li Y-F, Li X-X, Li M, Duan Y-F, Chen L, Wang X-R. 2020. Phylogeography and the population genetic structure of flowering cherry Cerasus serrulata (Rosaceae) in subtropical and temperate China. Ecology and Evolution 10:11262-11276. DOI: $10.1002 /$ ece 3.6765. 
Figure 1

Map of localities of Caquena and Lauca sub-basins. 


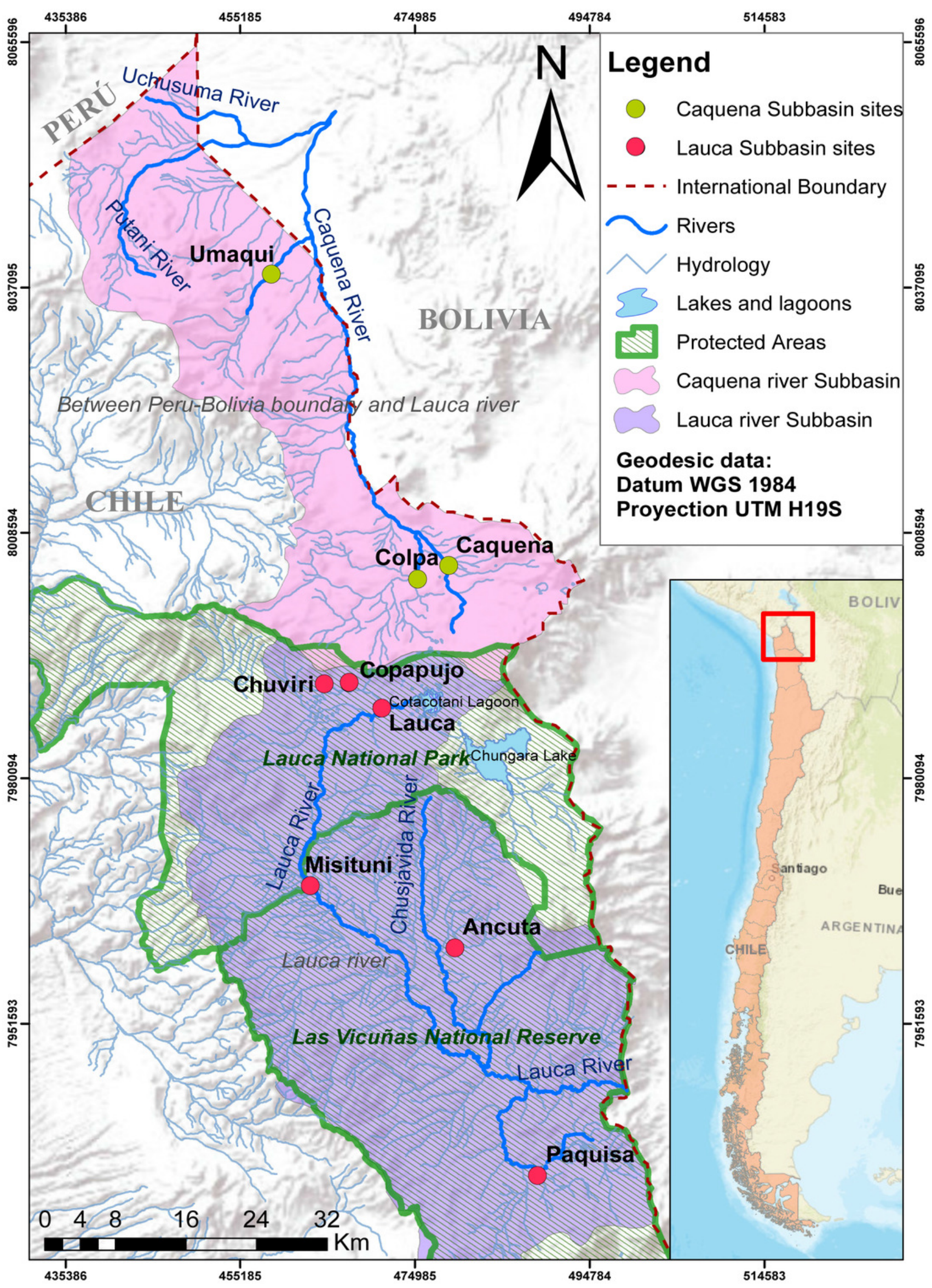


Figure 2

Haplotype network based on a median joining criterion of the studied locations of Lauca and Caquena sub-basins.

Circles represent haplotypes, while the length of the main lines is proportional to the number of mutational steps between haplotypes. Short black lines that intercept the main lines correspond to mutational steps between haplotypes.

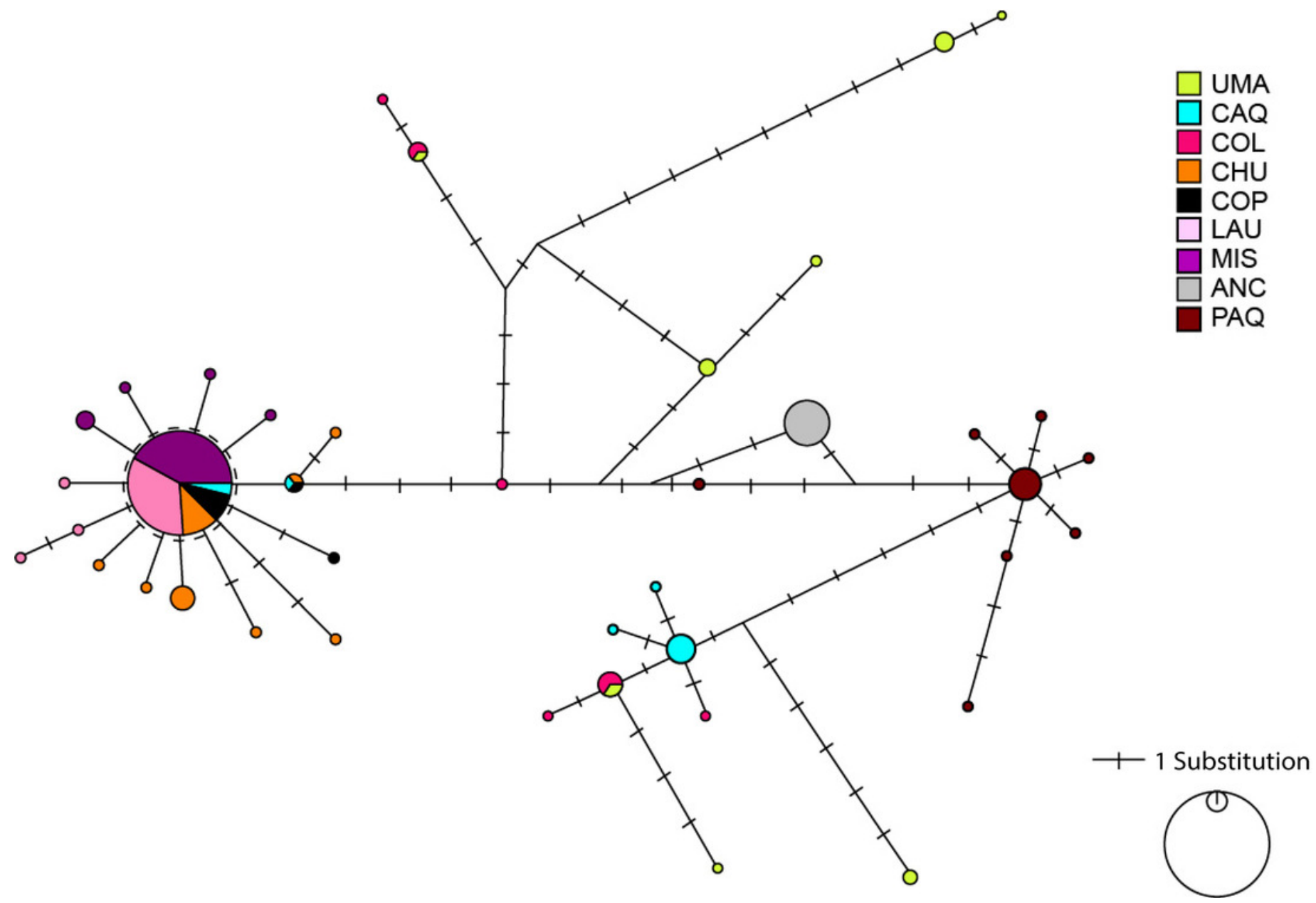


Figure 3

Haplotype network based on a median joining criterion and mismatch distribution.

(A) Umaqui. (B) Caquena. (C) Colpa. (F) Paquisa. It was not possible to build this for Ancuta because it only presented one haplotype. 

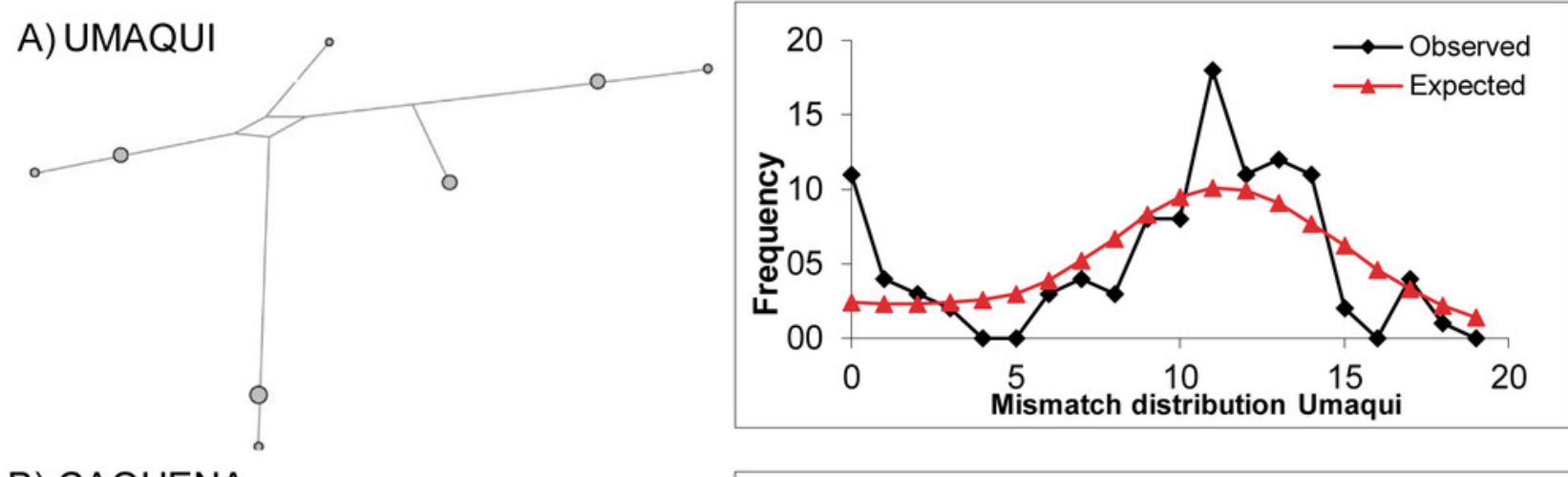

\section{B) CAQUENA}
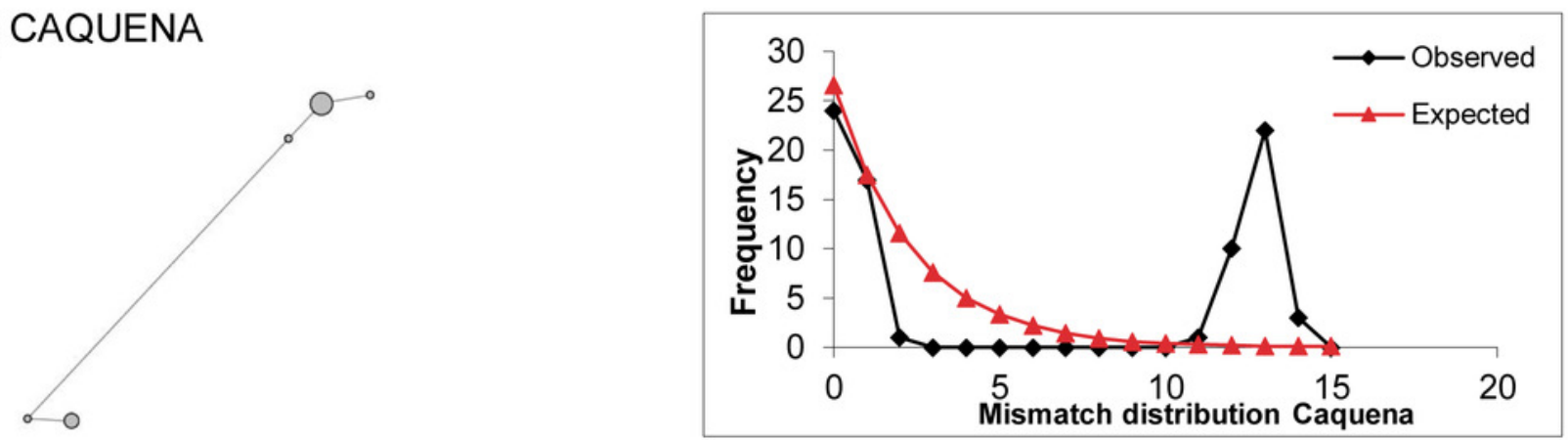

C) COLPA
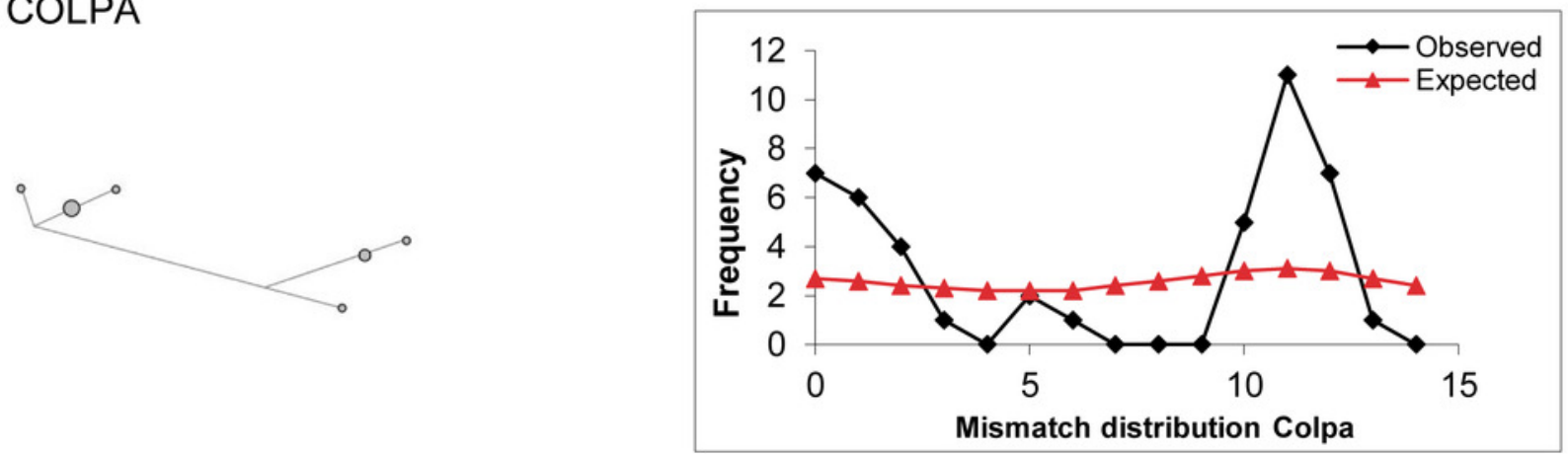

D) PAQUISA
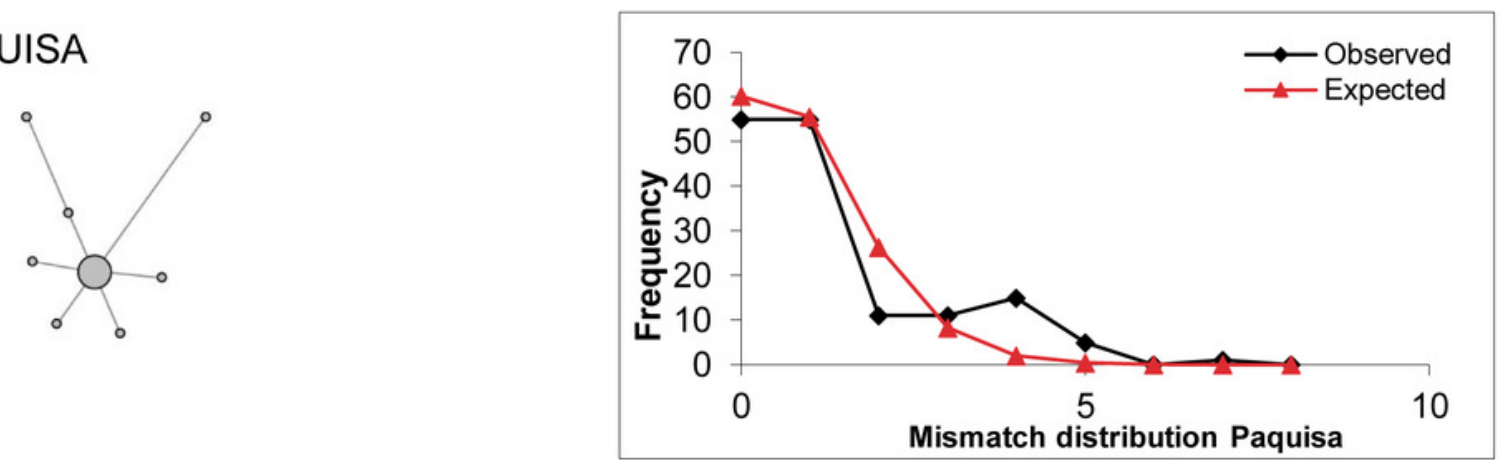


\section{Figure 4}

Demographic history from a Bayesian skyline plot analysis estimated using mitochondrial control region sequences of Orestias groups: A) Umaqui, B) Caquena, C) Colpa, D) LNP group and E) Paquisa.

The $x$-axis shows the Time in years and y-axis shows the Population size as the product of effective population size ( $\mathrm{Ne}$ ) and generation time (t). The black solid line represents the median estimate of the estimated effective population size, and 95\% highest probability density (HPD) interval corresponds to the shaded blue area. The segmented line corresponds to the estimated time of the most recent common ancestor (TMRCA) and the purple and red solid lines on $D$ ) and E) respectively correspond to the estimated time for the expansion of that populations. 


\section{A) UMAQUI}

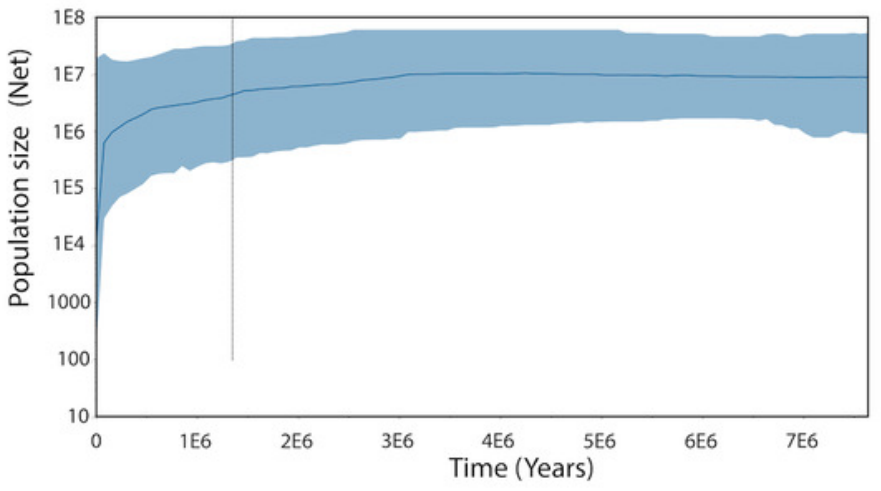

B) CAQUENA

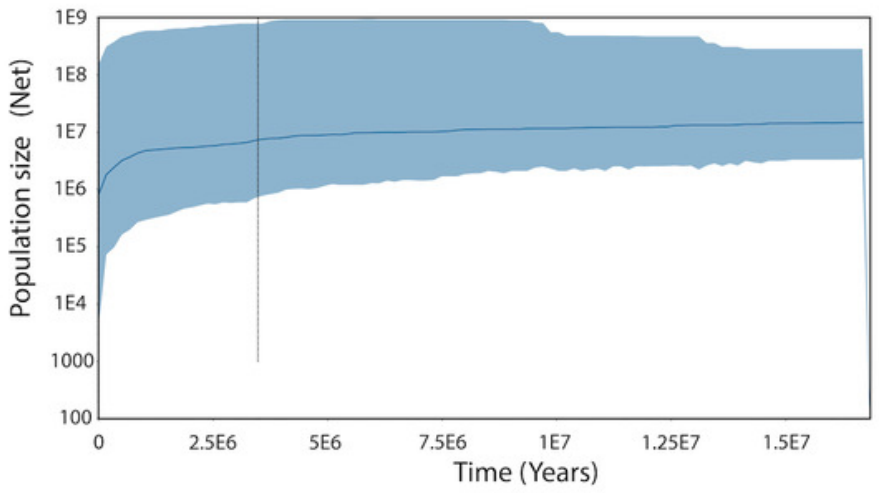

C) COLPA

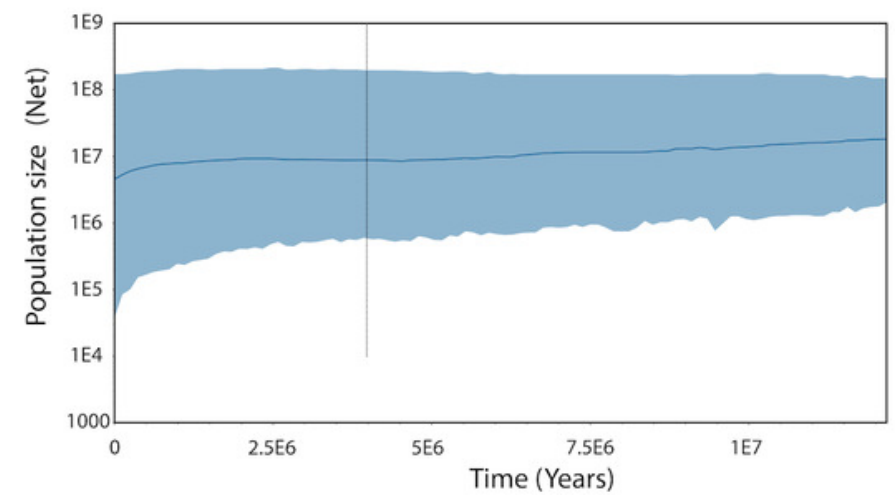

D) LNP

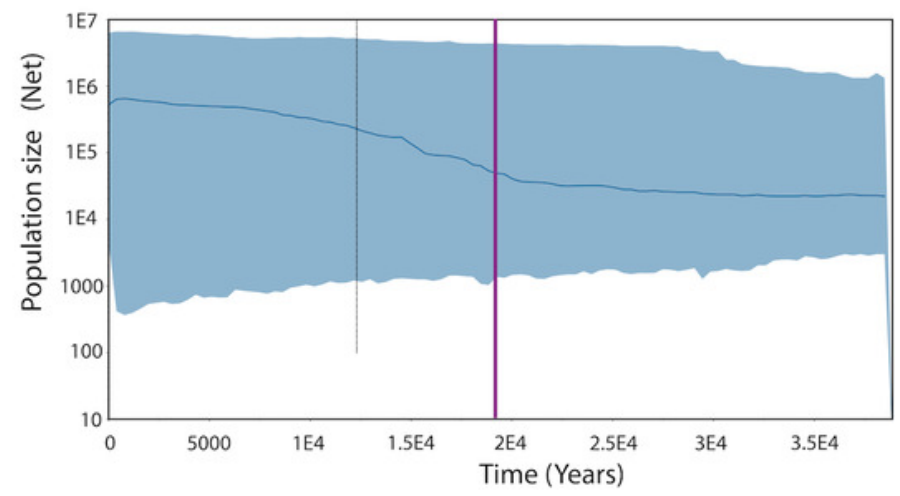

E) PAQUISA

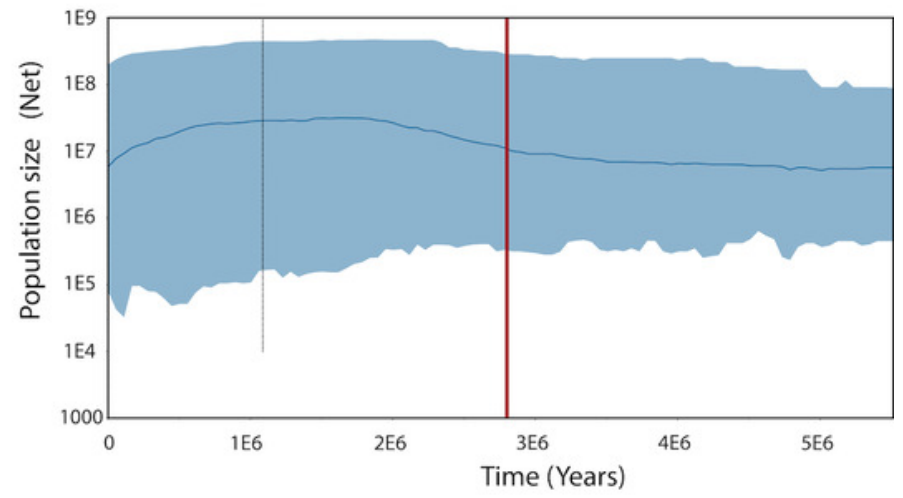


Figure 5

Reassignment percentages of studied locations

Reference locations are on the $X$ axis and the percentage of reassignment is on the $Y$ axis.

Different colors of the bars represent the percentage of individuals from each assigned location. The colors of each locality are the same as in the haplotype network.

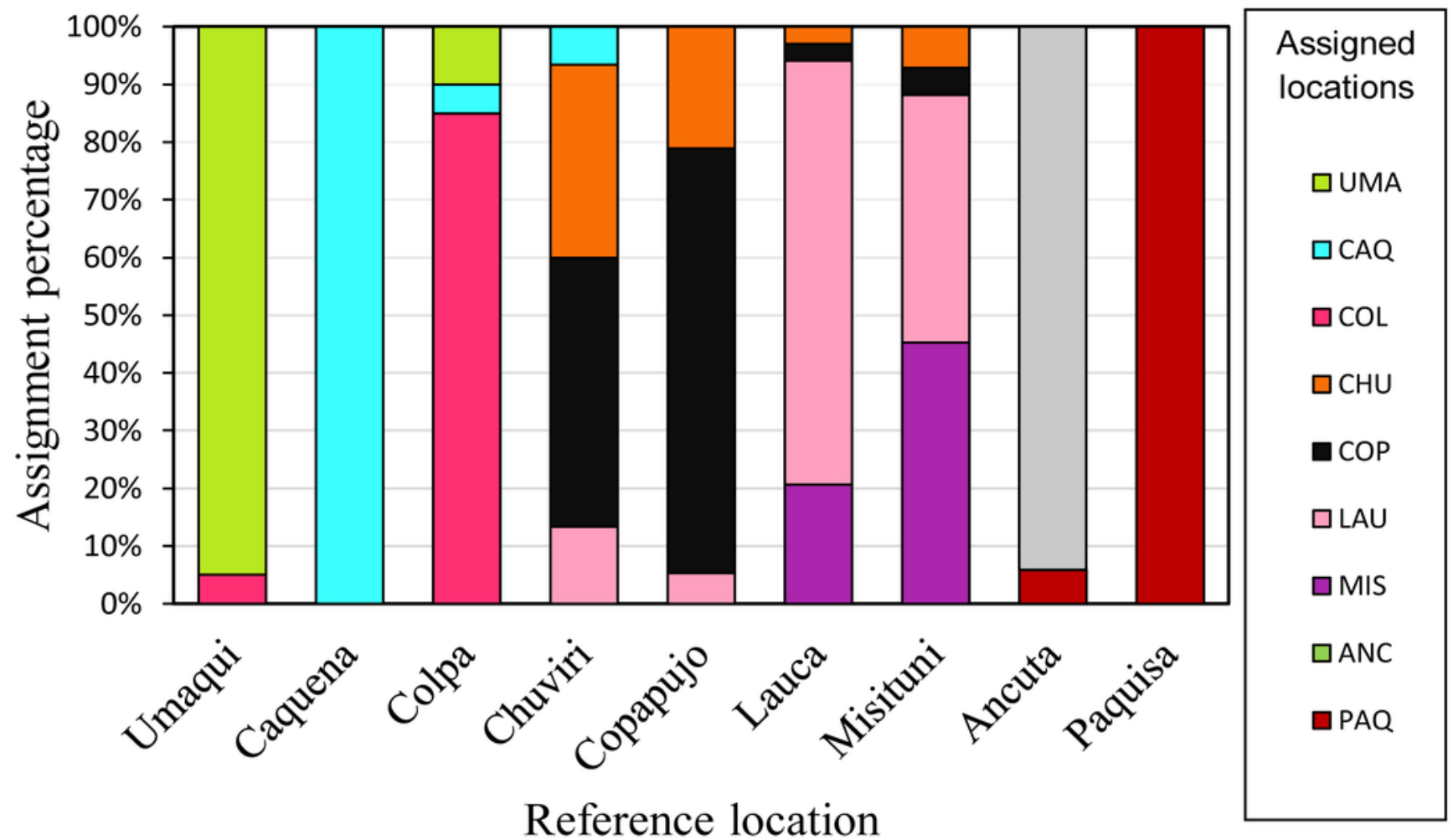




\section{Figure 6}

Results of the analysis of genetic structuring and cluster assignment (Structure) for all locations analyzed with $\mathrm{k}=5$.

Each vertical line represents an individual, grouped according to their place of origin separated by black lines. Each color corresponds to a genetic group. The different colors in each individual represent their probability of assignment to that genetic group.

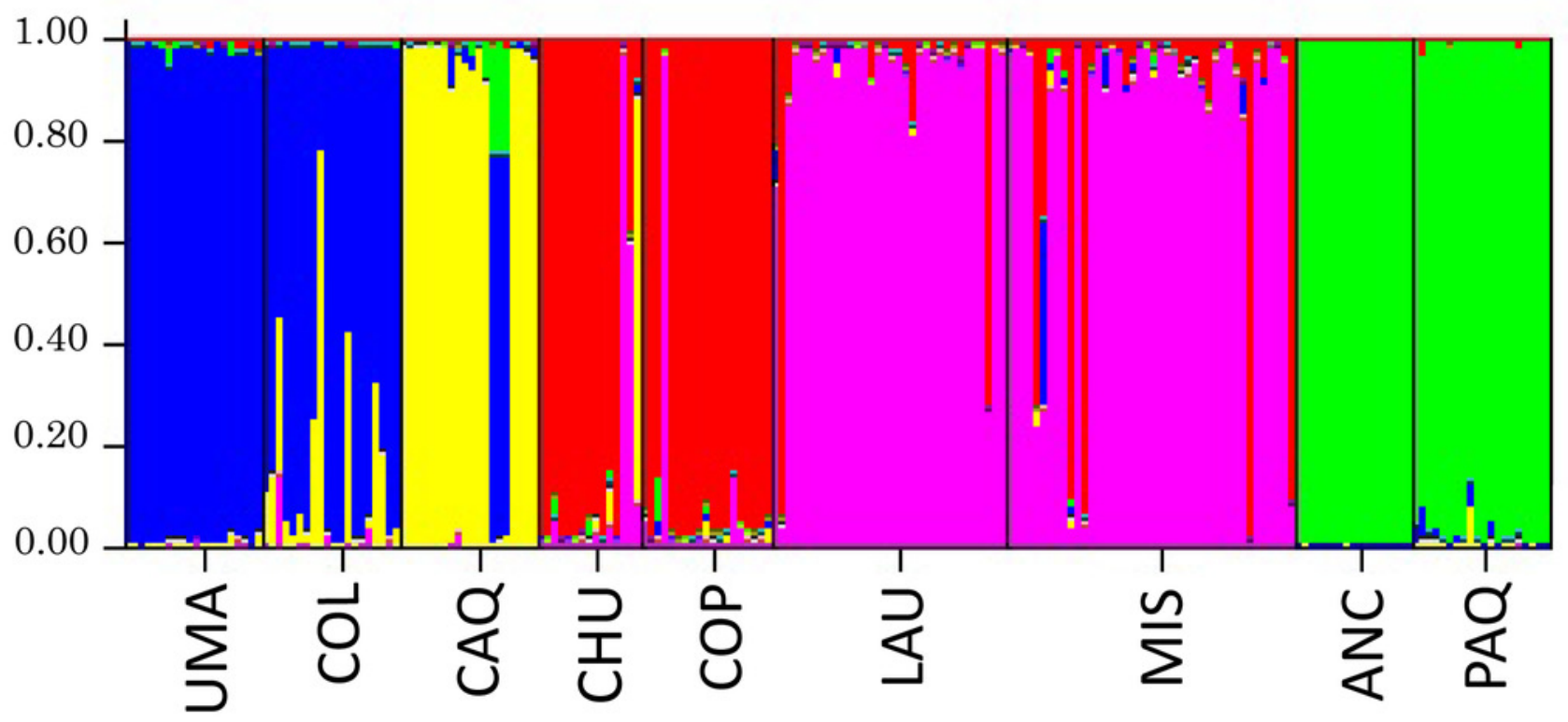


Figure 7

\section{Timeline and diagram of results interpretation}

Fish color icons are the same as the haplotypes used in the haplotype network of results.

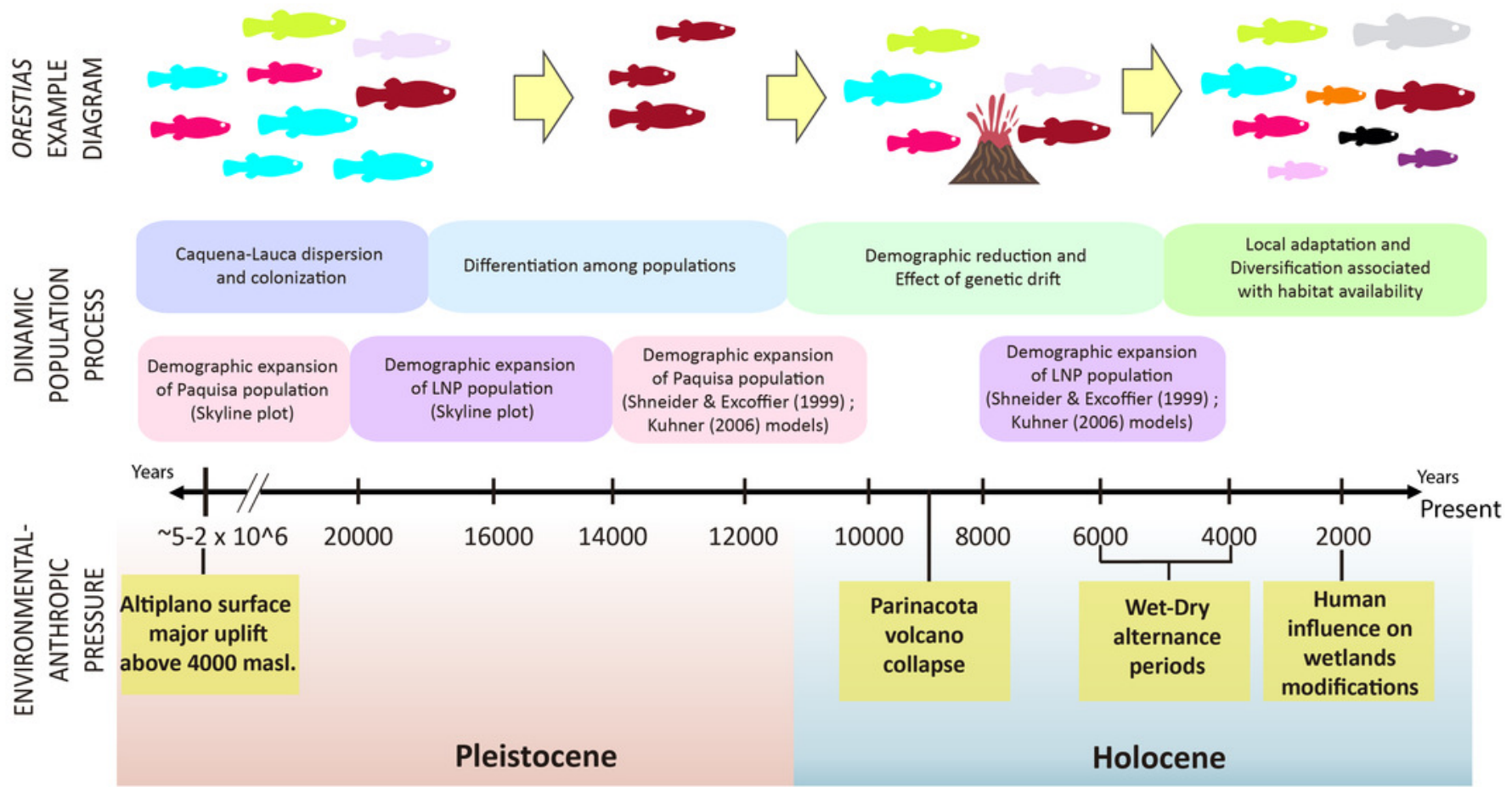


Table $\mathbf{1}$ (on next page)

Geographic coordinates of the locations studied. 
1

2

3

4

5

6

7

8

9

10

11

12

13

14

15

16

17

\begin{tabular}{|l|c|c|c|c|}
\hline \multirow{3}{*}{ Sub-basin } & \multirow{2}{*}{ Location } & \multirow{2}{*}{ Abbreviation } & \multicolumn{2}{|c|}{ Coordinates $\left(^{\circ}\right)$} \\
\cline { 4 - 5 } & & & South & West \\
\hline \multirow{4}{*}{ Caquena } & Umaqui & UMA & 17.73926 & 69.39064 \\
\cline { 2 - 5 } & Caquena & CAQ & 18.04527 & 69.20166 \\
\cline { 2 - 5 } & Colpa & COL & 18.05816 & 69.23445 \\
\hline \multirow{5}{*}{ Lauca } & Chuviri* & CHU & 18.16925 & 69.33481 \\
\cline { 2 - 5 } & Copapujo* & COP & 18.16925 & 69.30785 \\
\cline { 2 - 5 } & Lauca* & LAU & 18.19379 & 69.27360 \\
\cline { 2 - 5 } & Misituni* & MIS & 18.38074 & 69.34920 \\
\cline { 2 - 5 } & Ancuta & ANC & 18.44611 & 69.19486 \\
\cline { 2 - 5 } & Paquisa & PAQ & 18.68510 & 69.10563 \\
\hline
\end{tabular}

*Data

from Guerrero-Jiménez et al (2017) 


\section{Table 2 (on next page)}

Microsatellite loci characteristics and MIX assigned.

Modified from Esquer-Garrigos et al (2011) 


\begin{tabular}{|c|c|c|c|c|}
\hline Locus & Primer (5'-3') & Dye label & $\begin{array}{c}\text { Temperature } \\
\text { Alignment }\left({ }^{\circ} \mathrm{C}\right)\end{array}$ & MIX \\
\hline A9a & $\begin{array}{l}\text { F: CAGGAAGGAATCTCAGGAATG } \\
\text { R: ACGCACCGTTTCATAGTAAGG }\end{array}$ & FAM & 58 & \multirow{4}{*}{1} \\
\hline A106 & $\begin{array}{l}\text { F: TGGCTGATGGTATTGGTTG } \\
\text { R: AGCACACCTTCACAGGATG }\end{array}$ & VIC & 60 & \\
\hline B1 & $\begin{array}{l}\text { F: TACAAACACATCCATCTCAGTC } \\
\text { R: AACACTCCTATCATCCATCATC }\end{array}$ & PET & 58 & \\
\hline $\mathrm{C} 102$ & $\begin{array}{l}\text { F: TTCCAAACCACATTTTAGATCC } \\
\text { R: CAGCCTTTTGATTATGGAGGT }\end{array}$ & NED & 63 & \\
\hline A116 & $\begin{array}{c}\text { F: TCGCTACTTACTCCGACCTC } \\
\text { R: AAATCACAATGGCTTTCTCTG }\end{array}$ & PET & 54 & \multirow{4}{*}{2} \\
\hline B104 & $\begin{array}{l}\text { F: ACCGTAGTTGCCTGGTTACA } \\
\text { R: AGGGTGCTGTCAGAGATGAG }\end{array}$ & VIC & 64 & \\
\hline $\mathrm{C} 105$ & $\begin{array}{c}\text { F: AGCAAGACCAGTTTGAAATCT } \\
\text { R: GTTGCCCTGCGATGTAC }\end{array}$ & NED & 58 & \\
\hline D110 & $\begin{array}{c}\text { F: ATCACAAGACGAGGTTCTCAC } \\
\text { R: GATTGGAGCAAGGGACTG }\end{array}$ & FAM & 59 & \\
\hline B103 & $\begin{array}{c}\text { F: TATTATCCACTCCTGGTCAGTC } \\
\text { R: GTTGAAGCGTTTCCAAGAT }\end{array}$ & FAM & 51 & 3 \\
\hline
\end{tabular}




\section{Table 3 (on next page)}

Genetic diversity indexes of D-loop sequences of Orestias from studied locations.

$\mathrm{N}$ : sample size; S: polymorphic sites; K: haplotype number; []: rarefaction of number of haplotypes; Hd: haplotype diversity; П: mean number of differences between pairs of sequences; $\pi$ : nucleotide diversity. 


\begin{tabular}{|c|c|c|c|c|c|c|c|}
\hline $\begin{array}{l}\text { Sub- } \\
\text { basin }\end{array}$ & Location & $\mathrm{N}$ & $\mathrm{S}$ & $\mathrm{K}$ [rarefaction] & $\mathrm{Hd}$ & $\Pi$ & $\pi$ \\
\hline \multirow{3}{*}{ Caquena } & UMA & 15 & 26 & $8[6.450+/-0.827]$ & $0.895+/-0.053$ & $9.467+/-4.604$ & $0.012+/-0.006$ \\
\hline & CAQ & 13 & 14 & $5[4.30+/-0.665]$ & $0.692+/-0.119$ & $6.128+/-3.118$ & $0.008+/-0.004$ \\
\hline & $\mathrm{COL}$ & 10 & 16 & 6 & $0.844+/-0.103$ & $6.689+/-3.448$ & $0.008+/-0.005$ \\
\hline \multirow{6}{*}{ Lauca } & $\mathrm{CHU}^{*}$ & 23 & 11 & $9[5.552+/-1.087]$ & 0.755 & 1.621 & 0.00182 \\
\hline & $\mathrm{COP} *$ & 11 & 4 & 4 & 0.600 & 1.055 & 0.00118 \\
\hline & LAU* & 37 & 3 & $4[1.89+/-0.76]$ & 0.158 & 0.213 & 0.00024 \\
\hline & MIS* & 48 & 6 & $7[2.467+/-0.924]$ & 0.340 & 0.368 & 0.00041 \\
\hline & ANC & 20 & 0 & $1[1+/-0]$ & $0.000+/-0.000$ & $0.000+/-0.000$ & $0.000+/-0.000$ \\
\hline & PAQ & 18 & 11 & $8[8+/-0]$ & $0.641+/-0.130$ & $1.320+/-0.862$ & $0.002+/-0.001$ \\
\hline \multicolumn{2}{|c|}{ TOTAL } & 195 & 54 & 40 & 0.727 & 6.285 & 0.00771 \\
\hline
\end{tabular}

13 


\section{Table 4(on next page)}

Genetic differentiation for locations studied based on haplotype differences $\left(F_{S T}\right)$ and number of differences between pairs of sequences $\left(\Phi_{\mathrm{ST}}\right)$ based on D-loop marker.

Over diagonal is the significance of each comparison; NS=non-significant, ${ }^{*}=p<0.05$, $* *=p<0.001$ and $* * *=p<0.0001$. Double line separates the locations of each sub-basin. 


\begin{tabular}{|c|c|c|c||c|c|c|c|c|c|}
\hline \multirow{2}{*}{ F $_{\text {ST }}$} & \multicolumn{3}{|c|}{ Caquena sub-basin } & \multicolumn{6}{c|}{ Lauca sub-basin } \\
\cline { 2 - 12 } & UMA & CAQ & COL & CHU & COP & LAU & MIS & ANC & PAQ \\
\hline UMA & - & $* * *$ & NS & $* * *$ & $* * *$ & $* * *$ & $* * *$ & $* * *$ & $* * *$ \\
\hline CAQ & 0.20378 & - & $* *$ & $* *$ & $* *$ & $* * *$ & $* * *$ & $* * *$ & $* * *$ \\
\hline COL & 0.06675 & 0.23559 & - & $* *$ & $* * *$ & $* * *$ & $* * *$ & $* * *$ & $* * *$ \\
\hline \hline CHU & 0.19611 & 0.19986 & 0.22456 & - & NS & $* * *$ & $* * *$ & $* * *$ & $* * *$ \\
\hline COP & 0.35877 & 0.34594 & 0.41186 & 0.09172 & - & NS & NS & $* * *$ & $* * *$ \\
\hline LAU & 0.57288 & 0.56382 & 0.64004 & 0.25104 & 0.01357 & - & NS & $* * *$ & $* * *$ \\
\hline MIS & 0.53883 & 0.51535 & 0.59371 & 0.21757 & -0.00669 & -0.00072 & - & $* * *$ & $* * *$ \\
\hline ANC & 0.5959 & 0.71229 & 0.6884 & 0.62099 & 0.8751 & 0.89908 & 0.84069 & - & $* * *$ \\
\hline PAQ & 0.23615 & 0.33546 & 0.26941 & 0.31605 & 0.48565 & 0.66046 & 0.62494 & 0.69262 & - \\
\hline Ф & & \multicolumn{1}{|c|}{} & \multicolumn{1}{|c|}{} & & & & & \\
\hline UMA & - & $*$ & $*$ & $* * *$ & $* * *$ & $* * *$ & $* * *$ & $* * *$ & $* * *$ \\
\hline CAQ & 0.19778 & - & NS & $* * *$ & $* *$ & $* * *$ & $* * *$ & $* * *$ & $* * *$ \\
\hline COL & 0.11547 & 0.07463 & - & $* * *$ & $* * *$ & $* * *$ & $* * *$ & $* * *$ & $* * *$ \\
\hline \hline CHU & 0.64063 & 0.66901 & 0.74684 & - & NS & $* * *$ & $* * *$ & $* * *$ & $* * *$ \\
\hline COP & 0.57269 & 0.61894 & 0.70361 & 0.02789 & - & NS & NS & $* * *$ & $* * *$ \\
\hline LAU & 0.74491 & 0.78465 & 0.85076 & 0.10726 & 0.04145 & - & NS & $* * *$ & $* * *$ \\
\hline MIS & 0.7765 & 0.81096 & 0.87065 & 0.11986 & 0.04306 & 0.01728 & - & $* * *$ & $* * *$ \\
\hline ANC & 0.59147 & 0.70938 & 0.72001 & 0.92075 & 0.97654 & 0.98285 & 0.97868 & - & $* * *$ \\
\hline PAQ & 0.50848 & 0.56525 & 0.56178 & 0.88715 & 0.90679 & 0.94745 & 0.9508 & 0.81725 & - \\
\hline
\end{tabular}




\section{Table 5 (on next page)}

Estimation of effective population size and demographic expansion time under the assumptions of the models of Schneider \& Excoffier (1999) and Kuhner (2006), evaluated in Paquisa and PNL (Lauca, Misituni, Copapujo, Chuviri).

$\tau=$ tau, $\mu=$ nucleotide substitution rate, $\mathrm{t}=$ time from expansion (in mutational time units), $\mathrm{N}_{e} 0=$ initial effective size, $\mathrm{N}_{\mathrm{e}} \mathrm{l}=$ final effective size, $\mathrm{G}=$ growth rate, $\mathrm{Ne}_{\mathrm{i}}=$ initial effective size, $\mathrm{Ne}_{\mathrm{f}}=$ final effective size, []=confidence interval. 
Demographic expansion model of Schneider \& Excoffier (1999) Arlequin v. 3.5.1

\begin{tabular}{|c|c|c|c|c|}
\hline PNL & $\tau=2 \mu \mathrm{t}$ & $\mathrm{N}_{\mathrm{e}} 0$ & $\mathrm{~N}_{\mathrm{e}} 1$ & Time (years) \\
\hline Paquisa & $\begin{array}{c}0.342 \\
{[0-2.02]}\end{array}$ & 7546.01 & 16150.31 & $\begin{array}{c}5245 \\
{[0-37653]}\end{array}$ \\
\hline $\begin{array}{c}0.965 \\
{[0-2.094]}\end{array}$ & 0 & 300546.01 & $\begin{array}{c}14800 \\
{[0-32055]}\end{array}$ \\
\hline
\end{tabular}

Coalescence model of likelihood Kuhner (2006) LAMARC v.3.2

\begin{tabular}{|c|c|c|c|c|}
\hline & $\mathrm{G}$ & $\mathrm{Ne}_{\mathrm{i}}$ & $\mathrm{Ne}_{\mathrm{f}}$ & Time (years) \\
\hline PNL & & & & \\
& 14701.9 & 34865.8 & $3.32^{*} 10^{6}$ & 7750 \\
& {$[19292.9-$} & {$[76900.2-$} & {$\left[6.50^{*} 10^{6}-\right.$} & $\left.1.15^{*} 10^{6}\right]$ \\
& $11128.6]$ & $11993.3]$ & & \\
& & & & \\
\hline \multirow{5}{*}{ Paquisa } & 12374.5 & $6.59 * 10^{6}$ & $6.42^{*} 10^{8}$ & 9250 \\
& {$[17953.9-$} & {$\left[2.11^{*} 10^{8}-\right.$} & {$\left[1.88^{*} 10^{10}-\right.$} & {$[6250-17500]$} \\
& $6510.2]$ & $\left.3.72 * 10^{4}\right]$ & $\left.3.55^{*} 10^{6}\right]$ & \\
\hline
\end{tabular}




\section{Table 6(on next page)}

Genetic diversity indexes of eight microsatellite of Orestias of the studied locations.

$\mathrm{N}$ : number of individuals; A: mean number of alleles per locus [SD]: standard deviation; Hobs: observed heterozygosity; Hexp: expected heterozygosity; $F_{15}$ : endogamy index, NS= nonsignificant, $*=p<0.05$. 


\begin{tabular}{|c|c|c|c|c|c|c|}
\hline Sub-basin & Location & $\mathrm{N}$ & $\mathrm{A}$ & Hobs & Hexp & $\mathrm{F}_{\mathrm{IS}}$ \\
\hline \multirow{4}{*}{ Caquena } & UMA & 20 & 9.500 & 0.674 & 0.688 & $0.046^{\mathrm{NS}}$ \\
\cline { 2 - 7 } & CAQ & 20 & 6.125 & 0.543 & 0.548 & $0.035^{\mathrm{NS}}$ \\
\cline { 2 - 7 } & $\mathrm{COL}$ & 20 & 8.250 & 0.685 & 0.647 & $-0.034^{\mathrm{NS}}$ \\
\hline \multirow{5}{*}{ Lauca } & $\mathrm{CHU}$ & 15 & 4.375 & 0.453 & 0.451 & $0.038^{\mathrm{NS}}$ \\
\cline { 2 - 7 } & $\mathrm{COP}$ & 19 & 4.250 & 0.496 & 0.469 & $-0.012^{\mathrm{NS}}$ \\
\cline { 2 - 7 } & LAU & 34 & 5.250 & 0.520 & 0.513 & $0.004^{\mathrm{NS}}$ \\
\cline { 2 - 7 } & $\mathrm{MIS}$ & 42 & 6.625 & 0.493 & 0.538 & $0.097^{*}$ \\
\cline { 2 - 7 } & $\mathrm{ANC}$ & 17 & 3.125 & 0.309 & 0.303 & $0.012^{\mathrm{NS}}$ \\
\cline { 2 - 6 } & PAQ & 20 & 6.125 & 0.519 & 0.523 & $0.033^{\mathrm{NS}}$ \\
\hline
\end{tabular}




\section{Table 7 (on next page)}

Genetic differentiation of Orestias between pairs of locations $\left(\mathrm{F}_{\mathrm{ST}}\right)$ based on information of 8 microsatellite loci.

Above the diagonal is the significance of index values; NS=non-significant, $*=p<0.05$, $* *=p<0.001$ and $* * *=p<0.0001$. 


\begin{tabular}{|c|c|c|c|c|c|c|c|c|c|}
\hline $\mathrm{F}_{\mathrm{ST}}$ & $\mathrm{UMA}$ & $\mathrm{CAQ}$ & $\mathrm{COL}$ & $\mathrm{CHU}$ & $\mathrm{COP}$ & $\mathrm{LAU}$ & $\mathrm{MIS}$ & $\mathrm{ANC}$ & PAQ \\
\hline UMA & & $* * *$ & $*$ & $* * *$ & $* * *$ & $* * *$ & $* * *$ & $* * *$ & $* * *$ \\
\hline $\mathrm{CAQ}$ & 0.11508 & & $* * *$ & $* * *$ & $* * *$ & $* * *$ & $* * *$ & $* * *$ & $* * *$ \\
\hline COL & 0.03453 & 0.09327 & & $* * *$ & $* * *$ & $* * *$ & $* * *$ & $* * *$ & $* * *$ \\
\hline CHU & 0.26120 & 0.33904 & 0.29692 & & $\mathrm{NS}$ & $* * *$ & $* * *$ & $* * *$ & $* * *$ \\
\hline COP & 0.22754 & 0.31640 & 0.27715 & 0.00955 & & $* * *$ & $* * *$ & $* * *$ & $* * *$ \\
\hline LAU & 0.25316 & 0.30655 & 0.27420 & 0.09676 & 0.11751 & & $\mathrm{NS}$ & $* * *$ & $* * *$ \\
\hline MIS & 0.23674 & 0.29918 & 0.25849 & 0.07809 & 0.08711 & 0.00911 & & $* * *$ & $* * *$ \\
\hline ANC & 0.31965 & 0.31940 & 0.36195 & 0.50843 & 0.47407 & 0.42248 & 0.41178 & & $* * *$ \\
\hline PAQ & 0.15498 & 0.17257 & 0.18544 & 0.35136 & 0.31075 & 0.32431 & 0.31447 & 0.27961 & \\
\hline
\end{tabular}

